University of New Hampshire

University of New Hampshire Scholars' Repository

6-1-1997

\title{
Equilibrium responses of global net primary production and carbon storage to doubled atmospheric carbon dioxide: sensitivity to changes in vegetation nitrogen concentration
}

\author{
A. David McGuire \\ University of Alaska \\ Jerry M. Melillo \\ Marine Biological Laboratory \\ David W. Kicklighter \\ Marine Biological Laboratory (MBL) \\ Yude Pan \\ Xiangming Xiao
}

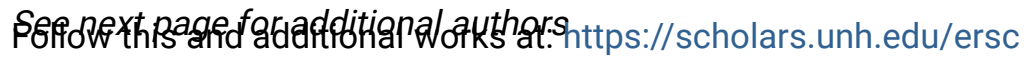

Comments

This is an article published by AGU in Global Biogeochemical Cycles in 1998, available online: https://dx.doi.org/

$10.1029 / 97 G B 00059$

\section{Recommended Citation}

McGuire AD, Melillo JM, Kicklighter DW, Pan Y, Xiao X, Helfrich J, Moore III B, Vorosmarty CJ, and AL Schloss (1997) Equilibrium responses of global net primary production and carbon storage to doubled atmospheric carbon dioxide: sensitivity to changes in vegetation nitrogen concentration, Global Biogeochemical Cycles, 11: 173-189. https://dx.doi.org/10.1029/97GB00059

This Article is brought to you for free and open access by the Institute for the Study of Earth, Oceans, and Space (EOS) at University of New Hampshire Scholars' Repository. It has been accepted for inclusion in Earth Systems Research Center by an authorized administrator of University of New Hampshire Scholars' Repository. For more information, please contact Scholarly.Communication@unh.edu. 


\section{Authors}

A. David McGuire, Jerry M. Melillo, David W. Kicklighter, Yude Pan, Xiangming Xiao, John Helfrich, Berrien Moore III, Charles J. Vorosmarty, and Annette L. Schloss 


\title{
Equilibrium responses of global net primary production and carbon storage to doubled atmospheric carbon dioxide: Sensitivity to changes in vegetation nitrogen concentration
}

\author{
A. David McGuire \\ U.S. Geological Survey, Alaska Cooperative Fish and Wildlife Research Unit, University of Alaska, Fairbanks \\ Jerry M. Melillo, David W. Kicklighter, Yude Pan, Xiangming Xiao, and John Helfrich \\ The Ecosystems Center, Marine Biological Laboratory, Woods Hole, Massachusetts
}

Berrien Moore III, Charles J. Vorosmarty, and Annette L. Schloss

Complex Systems Research Center, Institute for the Study of Earth, Oceans, and Space

University of New Hampshire, Durham

\begin{abstract}
We ran the terrestrial ecosystem model (TEM) for the globe at $0.5^{\circ}$ resolution for atmospheric $\mathrm{CO}_{2}$ concentrations of 340 and 680 parts per million by volume (ppmv) to evaluate global and regional responses of net primary production (NPP) and carbon storage to elevated $\mathrm{CO}_{2}$ for their sensitivity to changes in vegetation nitrogen concentration. At $340 \mathrm{ppmv}$, TEM estimated global NPP of $49.010^{15} \mathrm{~g}(\mathrm{Pg}) \mathrm{C} \mathrm{yr}^{-1}$ and global total carbon storage of $1701.8 \mathrm{Pg} \mathrm{C}$; the estimate of total carbon storage does not include the carbon content of inert soil organic matter. For the reference simulation in which doubled atmospheric $\mathrm{CO}_{2}$ was accompanied with no change in vegetation nitrogen concentration, global NPP increased $4.1 \mathrm{Pg} \mathrm{C} \mathrm{yr}^{-1}(8.3 \%)$, and global total carbon storage increased 114.2 Pg C. To examine sensitivity in the global responses of NPP and carbon storage to decreases in the nitrogen concentration of vegetation, we compared doubled $\mathrm{CO}_{2}$ responses of the reference TEM to simulations in which the vegetation nitrogen concentration was reduced without influencing decomposition dynamics ("lower N" simulations) and to simulations in which reductions in vegetation nitrogen concentration influence decomposition dynamics ("lower N+D" simulations). We conducted three lower $\mathrm{N}$ simulations and three lower $\mathrm{N}+\mathrm{D}$ simulations in which we reduced the nitrogen concentration of vegetation by $7.5,15.0$, and $22.5 \%$. In the lower $\mathrm{N}$ simulations, the response of global NPP to doubled atmospheric $\mathrm{CO}_{2}$ increased approximately $2 \mathrm{Pg} \mathrm{C}^{-1}$ for each incremental $7.5 \%$ reduction in vegetation nitrogen concentration, and vegetation carbon increased approximately an additional $40 \mathrm{Pg} \mathrm{C}$, and soil carbon increased an additional $30 \mathrm{Pg} \mathrm{C}$, for a total carbon storage increase of approximately $70 \mathrm{Pg} \mathrm{C}$. In the lower N+D simulations, the responses of NPP and vegetation carbon storage were relatively insensitive to differences in the reduction of nitrogen concentration, but soil carbon storage showed a large change. The insensitivity of NPP in the $\mathrm{N}+\mathrm{D}$ simulations occurred because potential enhancements in NPP associated with reduced vegetation nitrogen concentration were approximately offset by lower nitrogen availability associated with the decomposition dynamics of reduced litter nitrogen concentration. For each $7.5 \%$ reduction in vegetation nitrogen concentration, soil carbon increased approximately an additional $60 \mathrm{Pg} \mathrm{C}$, while vegetation carbon storage increased by only approximately $5 \mathrm{Pg} \mathrm{C}$. As the reduction in vegetation nitrogen concentration gets greater in the lower $\mathrm{N}+\mathrm{D}$ simulations, more of the additional carbon storage tends to become concentrated in the north temperateboreal region in comparison to the tropics. Other studies with TEM show that elevated $\mathrm{CO}_{2}$ more than offsets the effects of climate change to cause increased carbon storage. The results of this study indicate that carbon storage would be enhanced by the influence of changes in plant nitrogen concentration on carbon assimilation and decomposition rates. Thus changes in vegetation nitrogen concentration may have important implications for the ability of the terrestrial biosphere to mitigate increases in the atmospheric concentration of $\mathrm{CO}_{2}$ and climate changes associated with the increases.
\end{abstract}

Copyright 1997 by the American Geophysical Union.

Paper number 97GB00059.

0886-6236/97/97GB-00059\$12.00

\section{Introduction}

The atmospheric concentration of $\mathrm{CO}_{2}$ continues to increase because of human activity [Watson et al., 1990, 1992]. The 
1995 assessment of the Intergovernmental Panel on Climate Change (IPCC) indicates that atmospheric levels of $\mathrm{CO}_{2}$ could be greater than 800 parts per million by volume (ppmv) by the year 2100 if there is no change in the trend of fossil fuel use [IPCC Working Group I (WGI), 1996]. The buildup of $\mathrm{CO}_{2}$ in the atmosphere has the potential to affect net primary production (NPP) and carbon storage of terrestrial ecosystems. Net primary production is the rate at which vegetation in an ecosystem fixes carbon from the atmosphere (gross primary production) minus the rate at which it returns carbon to the atmosphere (plant respiration). The responses of NPP and carbon storage to elevated $\mathrm{CO}_{2}$ are important to understand because they may have substantial effects on humans. Because NPP represents food, fuel, and fiber for human consumption [Vitousek et al., 1986], the response of NPP may affect the availability of these resources. Rising levels of atmospheric $\mathrm{CO}_{2}$ have the potential to increase global surface air temperature and change precipitation and solar radiation patterns over the next century [Mitchell et al., 1990]. Because the response of carbon storage will affect the rate of $\mathrm{CO}_{2}$ accumulation in the atmosphere, it may influence the rate at which climate might change. Thus it is important to identify the potential range and spatial distribution of NPP and carbon storage responses to elevated atmospheric $\mathrm{CO}_{2}$.

A major uncertainty about the responses of NPP and carbon storage to elevated atmospheric $\mathrm{CO}_{2}$ concerns the role of the nitrogen cycle in these responses [McGuire et al., 1995a]. At the tissue level, an approximate doubling of atmospheric $\mathrm{CO}_{2}$ reduces leaf nitrogen concentration an average of $21 \%$ but has a smaller effect on nitrogen concentrations in stems and fine roots of woody plants [McGuire et al., 1995a]. On average, overall nitrogen concentration of woody plants decreases an average of $15 \%$ in response to an approximate doubling of atmospheric $\mathrm{CO}_{2}$ [McGuire et al., 1995a]. Although experimental research has confirmed that soil nitrogen availability often constrains the response of plant growth to elevated $\mathrm{CO}_{2}$, our knowledge of how $\mathrm{CO}_{2}$-induced changes in plant nitrogen concentration influences the response of NPP and carbon storage is based on a small number of studies [McGuire et al., 1995a]. Decreases in plant nitrogen concentration are hypothesized to influence NPP and carbon storage through the dynamics of carbon assimilation and decomposition.

The dynamics of carbon assimilation are influenced by leaflevel photosynthesis and ecosystem-level allocation responses to changes in tissue nitrogen concentrations. Among studies that manipulate both $\mathrm{CO}_{2}$ and nitrogen availability, a linear relationship exists between photosynthetic enhancement, change in leaf nitrogen concentration, and the amount of $\mathrm{CO}_{2}$ change according to the relationship:

$$
\mathrm{P}_{\mathrm{ne}} / \mathrm{P}_{\mathrm{nb}}=0.95924+0.00298 \mathrm{dL}_{\mathrm{N}}+0.00178 \mathrm{dC}_{\mathrm{a}}
$$

where $P_{n b}$ is net photosynthesis per unit leaf area for plants grown and measured at both baseline $\mathrm{CO}_{2}$ and the lowest level of fertilization in the experiment, $\mathrm{P}_{\mathrm{ne}}$ is the net photosynthesis rate for plants grown and measured at elevated $\mathrm{CO}_{2}$ and/or higher levels of nitrogen fertilization, $\mathrm{dL}_{\mathrm{N}}$ is the percent change in nitrogen concentration between leaves corresponding to the measurement of $P_{n b}$ and those of $P_{n e}$, and $d_{C}$ is the concentration difference in ppmv between elevated and baseline $\mathrm{CO}_{2}$ [see McGuire et al., 1995a]. For a 21\% decrease in leaf nitrogen concentration associated with a $340 \mathrm{ppmv}$ increase in atmos- pheric $\mathrm{CO}_{2}$, the leaf-nitrogen term indicates a relative photosynthetic reduction of $6.2 \%$, whereas the atmospheric- $\mathrm{CO}_{2}$ term indicates a relative photosynthetic increase of $60.5 \%$. Therefore at the tissue level, the influence of reductions in leaf nitrogen appear to be secondary compared with the rise in atmospheric $\mathrm{CO}_{2}$. In contrast, soil nitrogen availability is an important factor that often constrains the response of woody plant growth to elevated $\mathrm{CO}_{2}$ [see McGuire et al., 1995a]. This observation is consistent with numerous studies that have demonstrated that net primary production in northern and temperate ecosystems is known to be limited by the availability of inorganic nitrogen in the soil [Mitchell and Chandler, 1939; Safford and Filip, 1974; Van Cleve and Zasada, 1976; Auchmoody and Smith, 1977; Dodd and Lauenroth, 1979; Ellis, 1979; Shaver and Chapin, 1980; Risser et al., 1981; Miller, 1981; Aber et al., 1982; Peterson, 1982; Pastor et al., 1984; Binkley, 1986; Chapin et al., 1986; Shaver and Chapin, 1986; Chapin, 1991; Vitousek and Howarth, 1991]. Furthermore, it has been observed that production may increase substantially in response to increased soil nitrogen availability even when there is little response of tissue photosynthesis [see Vitousek et al., 1993]. The combination of evidence from $\mathrm{CO}_{2}$-manipulation studies and from nitrogen fertilization experiments suggests that the ecosystem-level response of carbon assimilation to elevated $\mathrm{CO}_{2}$ may depend on how nitrogen uptake by the vegetation and nitrogen recycling within the vegetation influence the ability of plants to incorporate elevated $\mathrm{CO}_{2}$ in the construction of canopy, stem, and root biomass. If elevated $\mathrm{CO}_{2}$ leads to a reduction in the nitrogen concentration of plant tissues, then the response of NPP to elevated $\mathrm{CO}_{2}$ may be enhanced because less nitrogen is involved in the construction of new biomass.

The effect of elevated $\mathrm{CO}_{2}$ in reducing nitrogen concentration of plant tissue may alter soil nitrogen availability by influencing decomposition. Compared to leaf litter of woody plants grown at baseline $\mathrm{CO}_{2}$, decreased nitrogen concentration for leaf litter of plants grown at elevated $\mathrm{CO}_{2}$ has been observed for numerous species [see McGuire et al., 1995a]. Rates of leaf decomposition are often correlated with several indices of nitrogen litter quality, which include nitrogen concentration, carbon/nitrogen ratio, and lignin/nitrogen ratio [Melillo et al., 1982]. Nitrogen concentration is generally positively correlated with decomposition, whereas the other two indices generally are negatively correlated. If decomposition is depressed because of $\mathrm{CO}_{2}$-induced changes in litter quality, soil nitrogen availability may be reduced in ecosystems. Because reduced nitrogen availability has the potential to limit productivity responses to elevated $\mathrm{CO}_{2}$, reduced litter quality resulting from elevated $\mathrm{CO}_{2}$ has the potential to cause long-term negative feedback to constrain the response of NPP.

Reductions in vegetation nitrogen concentration may have important implications for the role of the terrestrial biosphere in stabilizing the concentration of atmospheric $\mathrm{CO}_{2}$. These reductions may alter the $\mathrm{CO}_{2}$ response of NPP, which influences vegetation carbon storage, and the $\mathrm{CO}_{2}$ response of decomposition, which influences soil carbon storage. The response of vegetation carbon storage will depend on whether the potential for lower vegetation nitrogen concentration to enhance the response of NPP to elevated $\mathrm{CO}_{2}$ is stronger or weaker than the potential for lower litter quality to depress the NPP response. The response of soil carbon storage will depend on the degree 
to which decomposition rates are depressed by reductions in litter quality associated with lower vegetation nitrogen concentration.

Although reductions in vegetation nitrogen concentration associated with elevated atmospheric $\mathrm{CO}_{2}$ have the potential to influence carbon storage, it is not clear whether vegetation or soils will have a stronger response. In addition, there is uncertainty about the degree to which vegetation nitrogen concentration may respond to elevated $\mathrm{CO}_{2}$. Most studies of plant responses to elevated $\mathrm{CO}_{2}$ have involved experimental manipulation of developing seedlings. Because vegetation nitrogen concentration generally decreases during development, it has been argued that observed reductions in nitrogen concentration associated with elevated $\mathrm{CO}_{2}$ may, in part, represent accelerated growth [Agren, 1994]. In this study, we evaluate global and regional responses of NPP, vegetation carbon storage, and soil carbon storage to elevated $\mathrm{CO}_{2}$ for their sensitivity to changes in vegetation nitrogen concentration. For evaluating the sensitivity of these responses, we use version 4.0 of the terrestrial ecosystem model (TEM) [McGuire et al., 1995b], which is a biogeochemical model that makes geographically referenced estimates of the major carbon and nitrogen fluxes and pool sizes for the global terrestrial biosphere [see Melillo et al., 1993].

\section{Model Description}

\section{Overview}

The TEM uses spatially referenced information on climate, soils, and vegetation to make monthly estimates of important carbon and nitrogen fluxes and pool sizes for the terrestrial biosphere (Figure 1). The first two versions of TEM were used to examine patterns of NPP in South America [Raich et al., 1991] and North America [McGuire et al., 1992]. The third version of TEM was used to examine the response of NPP to elevated temperature and carbon dioxide for temperate forests [McGuire et al., 1993] and to general circulation model (GCM) predicted climate change for the terrestrial biosphere [Melillo et al., 1993]. The carbon storage predictions of the third version were also evaluated for global terrestrial ecosystems [Melillo et al., 1995] and for grasslands and conifer forests [McGuire et al., 1996]. In this study, we use version 4.0 of TEM, which was modified from version 3 to improve patterns of soil carbon storage along gradients of temperature, moisture, and soil texture [see McGuire et al., 1995b; vegetation/ecosystem modeling and analysis project (VEMAP) Members, 1995; Pan et al., 1996; Xiao et al., 1997]. Because the NPP and carbon storage responses of TEM to elevated $\mathrm{CO}_{2}$ and associated changes in vegetation nitrogen concentration will depend on the responses of both plant and soil processes in the model, we review the production and decomposition formulations in TEM.

\section{Production}

To understand how NPP estimated by TEM 4.0 responds to elevated atmospheric $\mathrm{CO}_{2}$, it is necessary to understand how NPP is determined. For each monthly time step in a model run, NPP is calculated as the difference between gross primary production (GPP) and plant respiration $\left(R_{A}\right)$. The calculation of $R_{A}$ considers both maintenance respiration [McGuire et al., 1992, 1993] and construction respiration [Raich et al., 1991]. The

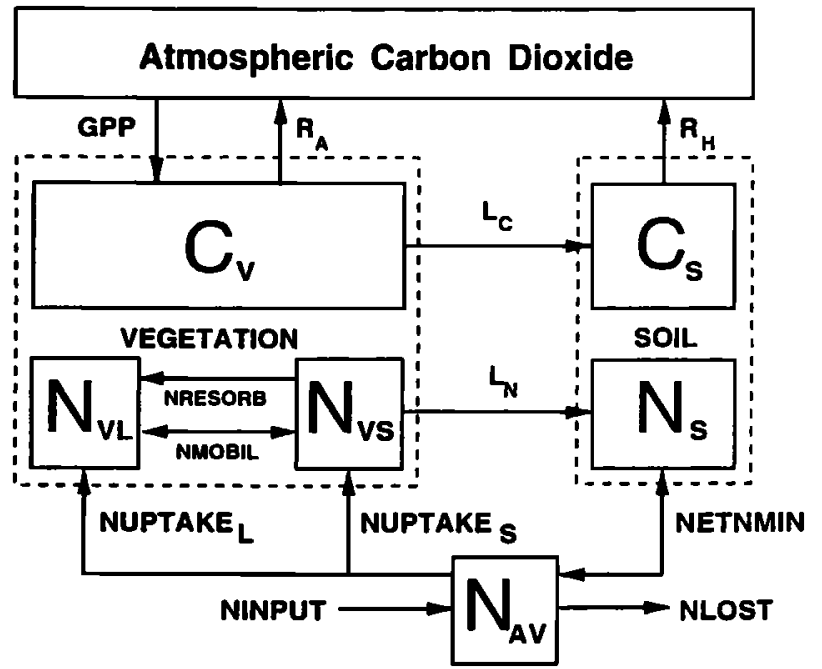

Figure 1. The Terrestrial Ecosystem Model (TEM). The state variables are carbon in the vegetation $\left(\mathrm{C}_{\mathrm{V}}\right)$; structural nitrogen in the vegetation $\left(\mathrm{N}_{\mathrm{vs}}\right)$; labile nitrogen in the vegetation $\left(\mathrm{N}_{\mathrm{VL}}\right)$; organic carbon in soils and detritus $\left(\mathrm{C}_{\mathrm{S}}\right)$; organic nitrogen in soils and detritus $\left(\mathrm{N}_{\mathrm{S}}\right)$; and available soil inorganic nitrogen $\left(\mathrm{N}_{\mathrm{AV}}\right)$. Arrows show carbon and nitrogen fluxes; GPP, gross primary production; $R_{A}$, autotrophic respiration; $R_{H}$, heterotrophic respiration; $L_{C}$, litterfall carbon; $\mathbf{L}_{\mathrm{N}}$, litterfall nitrogen; NUPTAKE $\mathrm{K}_{\mathrm{S}}$, nitrogen uptake into the structural nitrogen pool of the vegetation; NUPTAKE $_{\mathrm{L}}$, nitrogen uptake into the labile nitrogen pool of the vegetation; NRESORB, nitrogen resorption from dying tissue into the labile nitrogen pool of the vegetation; NMOBIL, nitrogen mobilized between the structural and labile nitrogen pools of the vegetation; NETNMIN, net nitrogen mineralization of soil organic nitrogen; NINPUT, nitrogen inputs from outside the ecosystem; and NLOST, nitrogen losses from the ecosystem.

flux GPP considers the effects of several factors and is calculated at each time step as follows:

$$
G P P=C_{\max } f(P A R) f(L E A F) f(T) f\left(C_{a}, G_{V}\right) f(N A)
$$

where $C_{\max }$ is the maximum rate of $C$ assimilation, PAR is photosynthetically active radiation, $\mathrm{LEAF}$ is leaf area relative to maximum annual leaf area, $\mathrm{T}$ is temperature, $\mathrm{C}_{\mathrm{a}}$ is atmospheric carbon dioxide, $\mathrm{G}_{\mathrm{V}}$ is relative canopy conductance, and NA is nitrogen availability.

The response of GPP to atmospheric $\mathrm{CO}_{2}$ is affected by three aspects of leaf-level carbon assimilation [Farquhar et al., 1980; Wullschleger, 1993; Pettersson and McDonald, 1994; Sage, 1994]: carboxylation, light harvest, and carbohydrate synthesis. Under saturating light conditions at low levels of intercellular $\mathrm{CO}_{2}$, assimilation is limited by the quantity and activity of ribulose bisphosphate carboxylase (rubisco), the enzyme that is primarily responsible for capturing atmospheric carbon in the production of sugars. Rubisco may accept either $\mathrm{CO}_{2}$ (carboxylation) or $\mathrm{O}_{2}$ (oxygenation) as a substrate; oxygenation leads to photorespiration. Because $\mathrm{CO}_{2}$ competes with $\mathrm{O}_{2}$ for rubisco binding sites, enhancement of photosynthesis by elevated $\mathrm{CO}_{2}$ is possible through increased carboxylation and decreased oxygenation. Carboxylation increases with rising intercellular $\mathrm{CO}_{2}$ until levels where the regeneration of rubisco, and thus the ability to fix carbon, is limited by the light harvesting 
machinery of photosynthesis. At high levels of intercellular $\mathrm{CO}_{2}$, the enzymatically controlled rate of carbohydrate synthesis, which affects the phosphate regeneration that is necessary for harvesting light energy, may regulate the fixation of carbon. The assimilation-intercellular $\mathrm{CO}_{2}\left(\mathrm{~A}-\mathrm{C}_{\mathrm{i}}\right)$ relationship is the empirical observation of carboxylation-limited, light-limited, and synthesis-limited assimilation over the range of intercellular $\mathrm{CO}_{2}$ [Wullschleger, 1993; Sage, 1994]. In TEM, the A-C relationship is represented by the product $f\left(C_{a}, G_{V}\right) f(N A)$.

Although the individual mechanisms of assimilation have been modeled [Farquhar et al., 1980; Farquhar and von Caemmerer, 1982], the A-C $\mathrm{C}_{\mathrm{i}}$ relationship can effectively be modeled with a hyperbolic relationship that collectively represents the mechanisms of assimilation. In TEM, the overall hyperbolic nature of the $\mathrm{A}-\mathrm{C}_{\mathrm{i}}$ relationship is represented in the function $\mathrm{f}\left(\mathrm{C}_{\mathrm{a}}, \mathrm{G}_{\mathrm{v}}\right)$ [Raich et al., 1991; McGuire et al., 1993; Melillo et al., 1993]:

$$
f\left(C_{a}, G_{v}\right)=C / /\left(k_{c}+C_{i}\right)
$$

where $\mathrm{C}_{\mathrm{i}}$ is the concentration of $\mathrm{CO}_{2}$ within leaves of the canopy and $\mathrm{k}_{\mathrm{c}}$ is the half-saturation constant for $\mathrm{CO}_{2}$ uptake by plants. The variable $\mathrm{C}_{\mathrm{i}}$ is the product of ambient $\mathrm{CO}_{2}\left(\mathrm{C}_{\mathrm{a}}\right)$ and relative canopy conductance to $\mathrm{CO}_{2}\left(\mathrm{G}_{\mathrm{V}}\right)$, a variable which increases from 0 to 1 with increasing water availability and depends on the ratio of actual evapotranspiration to potential evapotranspiration:

$$
\begin{array}{ll}
\mathrm{G}_{\mathrm{V}}=-10(\text { EET/PET })^{2}+2.9(\text { EET/PET }) & \text { EET/PET } \leq 0.1 \\
\mathrm{G}_{\mathrm{V}}=0.1+0.9(\text { EET/PET }) & \text { EET/PET }>0.1
\end{array}
$$

\section{EET/PET $\leq 0.1$}

where EET is estimated evapotranspiration and PET is potential evapotranspiration. The different form of $\mathrm{G}_{\mathrm{v}}$ below EET/PET of 0.1 allows minimum possible $G_{V}$ to be 0 instead of 0.1 , a plant response that seems possible in extremely arid regions. Because $G_{V}$ depends on the ratio of EET to PET, the response of $f\left(C_{a}, G_{v}\right)$ to doubled $\mathrm{CO}_{2}$ is higher in dry environments. The value of the parameter $k_{c}, 400 \mathrm{ppmv}$, has been chosen to increase $f\left(C_{a}, G_{v}\right)$ by $37 \%$ for a doubling of atmospheric $\mathrm{CO}_{2}$ from $340 \mathrm{ppmv}$ to $680 \mathrm{ppmv}$ for maximum relative canopy conductance, that is, $\mathrm{G}_{\mathrm{V}}=1$ [McGuire et al., 1992, 1993].

Although the range of response of plant growth is between 25 and $50 \%$ in studies that provide adequate nutrients and water to experimental plants [Kimball, 1975; Gates, 1985], soil nitrogen is an important factor that often constrains the response of woody plant growth to elevated $\mathrm{CO}_{2}$ [McGuire et al., 1995a]. The constraining effects of nitrogen availability on the response of carbon assimilation to elevated $\mathrm{CO}_{2}$ represents, in part, the acclimation response of photosynthesis to elevated $\mathrm{CO}_{2}$. Because rubisco represents a substantial proportion of leaf nitrogen [Evans, 1989], photosynthetic rate is generally correlated with the nitrogen content of leaves [Evans, 1989; Field, 1991]. Reduced nitrogen availability has often been observed to decrease both leaf nitrogen content and photosynthesis [Wong, 1979; Gulmon and Chu, 1981; Evans, 1983; Sage and Pearcy, 1987a,b; Chapin et al., 1988; Lajtha and Whitford, 1989]. Lower nitrogen concentrations of leaves in response to elevated $\mathrm{CO}_{2}$ may represent the dilution of nitrogen by higher rates of carbon assimilation or may represent less allocation of nitrogen to rubisco and other enzymes that influence light harvest and phosphate regeneration. If lower concentrations primarily represent dilution, then assimilation per unit leaf area should re- main unchanged over the carboxylation-limited range of intercellular $\mathrm{CO}_{2}$. Alternatively, if they represent less allocation of nitrogen to photosynthesis, then lower assimilation per unit leaf area is expected in plants grown at elevated $\mathrm{CO}_{2}$. This acclimation response of photosynthesis is categorized as down regulation, which occurs when the photosynthetic capacity of plants grown in elevated $\mathrm{CO}_{2}$ decreases in comparison to plants grown at baseline $\mathrm{CO}_{2}$, but the rate of photosynthesis for plants grown and measured at elevated $\mathrm{CO}_{2}$ is not less than the rate for plants grown and measured at baseline $\mathrm{CO}_{2}$ [see Luo et al., 1994]. Down regulation appears to be the predominant photosynthetic acclimation response of woody plants to elevated $\mathrm{CO}_{2}$ [Gunderson and Wullschleger, 1994; McGuire et al., 1995a].

In TEM, it is important to recognize that the response of GPP to doubled $\mathrm{CO}_{2}$ is not a constant $37 \%$ for $\mathrm{k}_{\mathrm{c}}$ of $400 \mathrm{ppmv}$ because of the effects of $f(N A)$ on the GPP calculation; $f(N A)$ models the limiting effects of plant nitrogen status on GPP through the feedback of nitrogen availability on carbon assimilation [McGuire et al., 1992, 1993; Melillo et al., 1993]. This feedback is dynamically determined by comparing the calculation of GPP based on nitrogen supply and the calculation of GPP for no constraints of nitrogen supply. Nitrogen supply is the sum of nitrogen uptake ((NUPTAKE), see Figure 1) plus nitrogen mobilized from the vegetation labile nitrogen pool ((NMOBIL), see Figure 1). The $\mathrm{C}$ to $\mathrm{N}$ ratio of production, which is represented by the parameter $\mathrm{P}_{\mathrm{CN}}$, is multiplied by the sum of NUPTAKE and NMOBIL to determine the amount of NPP that can be supported from the nitrogen supply. Nitrogen supply constrains production when the calculation of unconstrained GPP, that is, potential GPP $\left(\mathrm{GPP}_{\mathrm{P}}\right)$ for $\mathrm{f}(\mathrm{NA})$ equal to 1 , exceeds the sum of autotrophic respiration $\left(R_{A}\right)$ and NPP that is determined from nitrogen supply. Therefore the feedback of nitrogen availability on carbon assimilation, $\mathrm{f}(\mathrm{NA})$, is the ratio of GPP to GPP. The calculation of GPP, NPP, and $\mathrm{f}(\mathrm{NA})$ can be expressed as

$\mathrm{NPP}=\mathrm{P}_{\mathrm{CN}}(\mathrm{NUPTAKE}+\mathrm{NMOBI})$

$\mathrm{GPP}=\mathrm{P}_{\mathrm{CN}}(\mathrm{NUPTAKE}+\mathrm{NMOBI})+\mathrm{R}_{\mathrm{A}}$

$\mathrm{f}(\mathrm{NA})=\mathrm{GPP} / \mathrm{GPP}_{\mathrm{P}} \quad \mathrm{P}_{\mathrm{CN}}(\mathrm{NUPTAKE}+\mathrm{NMOBIL})+\mathrm{R}_{\mathrm{A}} \leq \mathrm{GPP}_{\mathrm{P}}$

and

$\mathrm{NPP}=\mathrm{GPP}_{\mathrm{P}}-\mathbf{R}_{\mathrm{A}}$

$\mathrm{GPP}=\mathrm{GPP}_{\mathrm{P}}$

$\mathrm{f}(\mathrm{NA})=1 \quad \mathrm{P}_{\mathrm{CN}}(\mathrm{NUPTAKE}+\mathrm{NMOBIL})+\mathrm{R}_{\mathrm{A}}>\mathrm{GPP}_{\mathrm{P}}$

On first inspection these algorithms would appear to completely constrain the response of NPP to elevated $\mathrm{CO}_{2}$ in nitrogen-limited systems. However, it is important to recognize that there is seasonality in the degree of nitrogen limitation. Nitrogen is generally in greatest supply early in the growing season when vegetation is able to mobilize nitrogen from storage. In this case, the vegetation in TEM is able to incorporate elevated intercellular $\mathrm{CO}_{2}$ into production. Higher levels of production cause greater litterfall to cause higher rates of decomposition and higher rates of nitrogen cycling. One consequence of greater nitrogen cycling is higher rates of nitrogen uptake. Nitrogen cycling eventually equilibrates at a higher level consistent with the higher levels of production and nitrogen supply. Thus elevated $\mathrm{CO}_{2}$ alters the seasonal pattern of carbon- 
nitrogen status in the vegetation of TEM to influence production.

\section{Decomposition}

The response of decomposition to elevated atmospheric $\mathrm{CO}_{2}$ may directly influence soil carbon storage through effects on litter quality that alter heterotrophic respiration rates. Decomposition may also influence soil carbon storage through effects on inorganic nitrogen availability that alter NPP and inputs into the soil; inorganic nitrogen availability depends, in part, on the net nitrogen mineralization ((NETNMIN), see Figure 1) of soil organic nitrogen that is associated with decomposition. In TEM, decomposition is represented as heterotrophic respiration $\left(\mathbf{R}_{\mathrm{H}}\right)$ :

$$
R_{H}=K_{d} C_{S} f(M) e^{0.0693 T}
$$

where $K_{d}$ is the heterotrophic respiration rate at $0^{\circ} \mathrm{C}, \mathrm{C}_{\mathrm{S}}$ is carbon storage in soils, $f(M)$ is a function defining the influence of soil moisture (M) on decomposition, and $\mathrm{T}$ is mean monthly air temperature. In TEM, $R_{H}$ is the only loss calculated from the detrital compartment $\mathrm{C}_{5}$, which is an aggregated pool of organic carbon in detritus and soils. The function $\mathrm{f}(\mathrm{M})$ is a nonlinear relationship that models the influence of soil moisture on microbial activity at low soil-moisture contents and the influence of oxygen availability on microbial activity at. high moisture contents [see Raich et al., 1991]). This relationship causes the highest rates of decomposition to occur when soils are $60 \%$ to $80 \%$ saturated with water, which has been observed in numerous laboratory and field studies [Bartholomew and Norman, 1946; Bhaumik and Clark, 1947; Miller and Johnson, 1964; Ino and Monsi, 1969; Hunt, 1977; Davidson, 1979; Sommers et al., 1981; Van Veen and Paul, 1981; Stott et al., 1986]. The exponential function with $T$ represents the temperature sensitivity of decomposition, which increases logarithmically with a $Q_{10}$ of 2.0 over all temperatures; soil respiration in temperate forests soils has a $\mathrm{Q}_{10}$ of 1.988 in relationships with mean daily air temperature and 1.983 in relationships with mean monthly air temperature [Kicklighter et al., 1994].

The parameter $\mathbf{K}_{d}$, which represents the heterotrophic respiration rate at $0^{\circ} \mathrm{C}$, is the rate-limiting parameter in the $R_{H}$ formulation. The value of $\mathbf{K}_{d}$ at a vegetation-specific calibration site $K_{\mathrm{dc}}$ is one of several rate-limiting parameters that are determined by calibrating TEM to the annual fluxes and pools at the calibration site for an ecosystem. To implement changes in litter quality associated with changes in vegetation nitrogen concentration, we relate $\mathrm{K}_{\mathrm{d}}$ to a power function of the carbon to nitrogen ratio of litterfall:

$$
\mathrm{K}_{\mathrm{d}}=\mathrm{K}_{\mathrm{dc}}\left(\mathrm{L}_{\mathrm{c}} / \mathrm{L}_{\mathrm{N}}\right)^{-0.784} /\left(\mathrm{L}_{\mathrm{Cc}} / \mathrm{L}_{\mathrm{Nc}}\right)^{-0.784}
$$

where $L_{C}$ and $L_{N}$ are the annual fluxes of litterfall carbon and nitrogen (see Figure 1) and $\mathrm{L}_{\mathrm{Cc}}$ and $\mathrm{L}_{\mathrm{Nc}}$ are the annual fluxes of litterfall carbon and nitrogen at the calibration site for the ecosystem. The implementation of this power function is based on the relationship derived by Melillo et al. [1982] for the decomposition of 13 leaf and needle species in the laboratory study of Daubenmire and Prusso [1963]. The relationship identifies that an inverse curvilinear relationship exists between the rate constant for annual mass loss, $\mathrm{k}$ [see Jenny et al., 1949], and the initial lignin to nitrogen ratio according a power function with the exponent -0.784 . We used this relationship instead of other relationships [see Melillo et al., 1982] because the data used to derive the relationship represents a wider range of lignin to nitrogen ratios than data used to derive other relationships; in TEM, the aggregated nature of litter inputs into the soil requires a relationship appropriate to a broad gradient of litter quality. Our implementation of this relationship to determine the dependence of $K_{d}$ on litter quality assumes that $K_{d}$ is proportional to $\mathrm{k}$ [see Raich et al., 1991] and that the ratio of $\mathrm{k}$ to (lignin/nitrogen) ${ }^{-0.784}$ is a constant [see Melillo et al., 1982]. Finally, we use the carbon to nitrogen ratio of litterfall in place of the initial lignin to nitrogen ratio of litterfall.

\section{Design of Sensitivity Analyses}

To examine sensitivity in the global responses of NPP and carbon storage to decreases in the nitrogen concentration of vegetation, we compare the reference doubled $\mathrm{CO}_{2}$ responses of TEM to the doubled $\mathrm{CO}_{2}$ responses of TEM for simulations in which the vegetation nitrogen concentration was reduced without influencing decomposition dynamics ("lower N" simulations) and simulations in which reductions in vegetation nitrogen concentration influence decomposition dynamics ("lower $\mathrm{N}+\mathrm{D}$ " simulations). We conducted three lower $\mathrm{N}$ simulations and three lower N+D simulations in which we reduced the nitrogen concentration of vegetation by $7.5,15.0$, and $22.5 \%$. We chose incremental reductions of $7.5 \%$ for the sensitivity analyses because the reduction is half of the average $15 \%$ reduction of nitrogen concentration in response to an approximate doubling of atmospheric $\mathrm{CO}_{2}$ [see McGuire et al., 1995a].

In modeling the acclimation response of GPP to elevated $\mathrm{CO}_{2}$, the assumption in TEM is that at monthly and annual timescales, there is a balance between canopy carbon assimilation and nitrogen economy of the vegetation. Thus in TEM, nitrogen is allocated implicitly to represent the tradeoff between canopy development and acclimation of tissue-level photosynthesis so that carbon uptake is maximized in building vegetative biomass at a specific carbon to nitrogen ratio. Although vegetative biomass is built at a specific carbon to nitrogen ratio, the overall ratio of carbon to nitrogen in vegetation may be different. For example, in tundra, the carbon to nitrogen ratio of new production is around 30 while the overall carbon to nitrogen ratio is around 50 [Shaver and Chapin 1991; McGuire et al., 1992]. These ratios are representative for the aggregated vegetation of a plant community, even though the ratios may be different for individual species and growth forms within the community [Shaver and Chapin, 1991]. The difference between the carbon to nitrogen ratios of new production and overall vegetative biomass are caused by the processes of nitrogen resorption and mobilization in plants. In TEM, nitrogen resorption is represented by the flux NRESORB and nitrogen mobilization is represented by the flux NMOBIL (see Figure 1).

Patterns of nitrogen resorption from senescing tissue and of mobilization of nitrogen from storage suggest that plants allocate nitrogen to maximize carbon uptake. The nitrogen that appears in new vegetative biomass comes from new uptake and from recycling, in which nitrogen is mobilized from storage. The resorption of nitrogen from senescing tissues is primarily responsible for the nitrogen in storage. In general, the degree of recycling is sensitive to the degree of nitrogen limitation. For example, production in tundra plants is more limited by nitro- 
gen availability than is production in boreal forest, which is more limited than production in temperate conifer forest [see McGuire et al., 1992]. In tundra plants, 50 to $80 \%$ of nitrogen in new tissue comes from resorption [Shaver and Chapin, 1991]. This is greater than the degree of recycling in boreal forest, in which approximately $45 \%$ of the nitrogen in new biomass comes from resorption [see $M c G$ uire et al., 1992]. In temperate conifer forest, the degree of recycling is less, with approximately $30 \%$ of nitrogen in new biomass derived from resorption [Sollins et al., 1980], and in tall grassland only $10 \%$ of the nitrogen in new biomass is derived from resorption [Risser et al., 1981]. These studies of nitrogen recycling indicate that plants are sensitive to carbon-nitrogen balance and suggest that plants are capable of conserving and allocating nitrogen to maximize carbon uptake. Because the parameters related to the nitrogen concentration of vegetation biomass in TEM define carbon-nitrogen balance in the model, it is important to understand the sensitivity of $\mathrm{CO}_{2}$ responses of TEM to potential changes that these parameters may experience in association with elevated atmospheric $\mathrm{CO}_{2}$.

Experimental studies that have measured the response of tissue nitrogen concentration in plants exposed to elevated $\mathrm{CO}_{2}$ usually do not identify whether the measurements represent changes in new production or in overall vegetative biomass. Therefore, in both the lower $\mathrm{N}$ and the lower $\mathrm{N}+\mathrm{D}$ simulations, we altered the parameters in TEM that control the vegetation carbon to nitrogen ratio $\left(V_{\mathrm{CN}}\right.$, [see Raich et al., 1991]) and the production carbon to nitrogen ratio $\left(\mathrm{P}_{\mathrm{CN}}\right.$, [see McGuire et al., 1992]). Because nitrogen concentration is inversely related to carbon to nitrogen ratio, we modified these parameters as follows:

$$
\begin{aligned}
& \mathrm{V}_{\mathrm{CN}}(\mathrm{d}[\mathrm{N}])=100 \mathrm{~V}_{\mathrm{CNo}} /(100-\mathrm{d}[\mathrm{N}]) \\
& \text { and } \\
& \mathrm{P}_{\mathrm{CN}}(\mathrm{d}[\mathrm{N}])=100 \mathrm{P}_{\mathrm{CNo}} /(100-\mathrm{d}[\mathrm{N}])
\end{aligned}
$$

where $V_{C N o}$ and $P_{C N o}$ are the original values of $V_{C N}$ and $P_{C N}$, and $V_{C N}(d[N])$ and $P_{C N}(d[N])$ are the values of $V_{C N}$ and $P_{C N}$ associated with the percent decrease in nitrogen concentration $(\mathrm{d}[\mathrm{N}])$; therefore $7.5,15.0$, and $22.5 \%$ decreases in nitrogen concentration increase $V_{\mathrm{CNo}}$ and $P_{\mathrm{CNo}}$ by $8.1,17.6$, and $29.0 \%$, respectively. In the reference and lower $N$ simulations, we set $K_{d}$ equal to $\mathrm{K}_{\mathrm{dc}}$ so that decomposition is not influenced by litter quality. In the lower $N+D$ simulations, we calculated $K_{d}$ based on its relationship with litter quality, which is influenced by the parameter $\mathrm{V}_{\mathrm{CN}}(\mathrm{d}[\mathrm{N}])$.

\section{Application of the Terrestrial Ecosystem Model}

The data sets used to drive TEM are gridded at a resolution of $0.5^{\circ}$ latitude by $0.5^{\circ}$ longitude. The variables required to run TEM 4.0 for a grid cell are mean monthly temperature, monthly precipitation, mean monthly cloudiness, vegetation, elevation, soil texture as percent silt plus clay, and several hydrological variables (potential evapotranspiration, estimated evapotranspiration, and soil moisture). Mean monthly temperature, precipitation, and cloudiness in this study are from the global data sets of Cramer and Leemans (W. Cramer, personal communication, 1995), which is a major update of Leemans and Cramer [1991]. Monthly percent cloudiness is calculated as 100 minus monthly percent sunshine duration in the Cramer and Leemans database. The vegetation data set, which identifies 18 dryland ecosystems, is similar to that of Melillo et al. [1993], but has been modified to represent the terrestrial boundaries defined by the Cramer and Leemans global database. The elevation data represent an aggregation to $0.5^{\circ}$ resolution of the $10^{\prime}$ National Center for Atmospheric Research (NCAR)/Navy [1984] data. Soil texture is based on the Food and Agriculture Organization (FAO)/Complex Systems Research Center (CSRC) (undated) digitization of the FAO-United Nations Educational, Scientific, and Cultural Organization (UNESCO) [1971] soils map. Hydrological data for TEM are determined by a water balance model [Vorosmarty et al., 1989] that uses the same input variables as TEM.

The application of TEM to a grid cell requires the use of the monthly climatic and hydrological data and the soil- and vegetation-specific parameters appropriate to the grid cell. Although many of the vegetation-specific parameters are defined from published information, some are determined by calibrating the model to the fluxes and pools sizes of an intensively studied field site. The run for each grid cell starts with the January values of the variables that have monthly temporal resolution. Therefore the initial values of the pool sizes for a grid cell are set to those of the December values from the appropriate vegetation-specific calibration. To determine a solution for baseline conditions, which in this study is defined as contemporary climate at an atmospheric $\mathrm{CO}_{2}$ concentration of $340 \mathrm{ppmv}$, the model is run with an open nitrogen cycle, and nitrogen is annually imported or exported through the inorganic nitrogen pool depending on whether soil organic matter is nitrogen poor or rich in comparison to the carbon to nitrogen ratio of the soil at the calibration site, $S_{\mathrm{CN}}$. This algorithm simulates the balance between long-term nitrogen inputs and outputs so that the grid cell has an equilibrium soil carbon to nitrogen ratio equal to $\mathrm{S}_{\mathrm{CN}}$; it has the benefit of reaching equilibrium much faster than explicitly simulating nitrogen fixation, nitrogen deposition, denitrification, and nitrogen leaching losses. The grid cell is determined to have reached equilibrium when the annual fluxes of NPP, $L_{C}$, and $R_{H}$ differ by less than $1 \mathrm{~g} \mathrm{C} \mathrm{m}^{-2} \mathrm{yr}^{-1}$, those of NETNMIN, $L_{N}$, and total $N$ uptake by vegetation differ by less than $0.01 \mathrm{~g} \mathrm{~N} \mathrm{~m}^{-2} \mathrm{yr}^{-1}$, and those of NINPUT and NLOST differ by less than $0.01 \mathrm{~g} \mathrm{~N} \mathrm{~m}^{-2} \mathrm{yr}^{-1}$. Because NINPUT and NLOST are determined annually, these fluxes are effectively 0 at equilibrium.

For running a grid cell under doubled $\mathrm{CO}_{2}(680 \mathrm{ppmv})$, the initial values of the pools for the grid cell are set to the December values of the equilibrium baseline solution for the grid cell, that is, the solution for $340 \mathrm{ppmv} \mathrm{CO}_{2}$. The nitrogen cycle is closed for the doubled $\mathrm{CO}_{2}$ run so that there is no nitrogen imported or exported from the grid cell. The conditions for determining when the grid cell has reached equilibrium are the same as for the baseline solution. For the reference doubled $\mathrm{CO}_{2}$ simulation, the mean amount of time for a grid cell to reach equilibrium was 76.6 years. For the lower $\mathrm{N}$ simulations associated with $7.5,15.0$, and 22.5 reductions in vegetation nitrogen concentration, the mean amount of time for a grid cell to reach equilibrium was $116.7,144.3$, and 169.2 years, respectively. For the lower $\mathrm{N}+\mathrm{D}$ simulations associated with 7.5, 15.0, and $22.5 \%$ reductions in vegetation nitrogen concentration, the mean amount of time for a grid cell to reach equilibrium was 
$157.8,192.5$, and 219.9 years, respectively. Because the turnover time of the single-compartment soil carbon pool in TEM is approximately 16 years, the simulations in this study represent true equilibrium solutions by the model. Although soil carbon is represented as a single compartment, the equilibrium solution is representative of the solution in a multiple-compartment model that considers the same total pool of soil organic carbon with similar formulations for each compartment. The implementation of the single-compartment model has the advantage of determining an equilibrium solution in less computational time than would be required by a multiple-compartment model (see Schimel et al. [1994] for analyses of single- versus multiple-compartment models of soil carbon dynamics).

\section{Results}

\section{Baseline Estimates of NPP and Carbon Storage}

At an atmospheric $\mathrm{CO}_{2}$ concentration of $340 \mathrm{ppmv}$, TEM 4.0 estimates global terrestrial NPP to be $49.010^{15} \mathrm{~g} \mathrm{(Pg)} \mathrm{C} \mathrm{yr}$ (Table 1). Much of the global NPP occurs in equatorial regions (Figure 2a) with $34.5 \%$ of global NPP in tropical evergreen forest, which occupies $13.7 \%$ of the terrestrial area (Table 1). In contrast, temperate forests (coniferous, deciduous, mixed, and broadleaf evergreen), which occupy $11.3 \%$ of the terrestrial area, account for $19.2 \%$ of global NPP (Table 1). A trough in productivity occurs between latitudes $10^{\circ}$ and $20^{\circ} \mathrm{N}$ (Figure 2a). These latitudes are largely occupied by deserts and arid shrublands, which account for only $3.9 \%$ of global NPP although they occupy $20.2 \%$ of global land area (Table 1). Similarly, high-latitude ecosystems (polar desert, tundra, boreal woodland, and boreal forest), which occupy $22.6 \%$ of terrestrial area, account for only $9.6 \%$ of global NPP (Table 1). The least productive vegetation types include polar desert, tundra, and desert, which collectively account for $2.4 \%$ of terrestrial NPP (Table 1).

For the baseline atmospheric $\mathrm{CO}_{2}$ concentration, global terrestrial carbon storage is estimated by TEM 4.0 to be $1701.8 \mathrm{Pg}$ $\mathrm{C}$, with 771.7 Pg C in soils and 930.1 Pg C in vegetation (Table 1). The estimate of vegetation carbon storage does not include the effects of land use. In previous studies, TEM estimates that land use reduces vegetation carbon stocks between 150 and 200 Pg C (D. W. Kicklighter, unpublished data, 1994). Because soil organic matter is composed of material that represents a spectrum of turnover times along the decay continuum [see Melillo et al., 1989a], we have designed TEM to exclude from its estimates of soil carbon storage that portion of soil organic matter which is biologically unreactive in the context of global change that might occur over the next century or so. In previous studies with TEM, we have estimated that the biologically unreactive soil organic carbon in this context represents 400 to $500 \mathrm{Pg} \mathrm{C}$ of the global soil carbon inventory [Melillo et al., 1995]. Several studies shed light on the spectrum of turnover times represented in soil carbon estimates of TEM. The terrestrial model of Sarmiento et al. [1995] estimates that approximately $350 \mathrm{Pg} \mathrm{C}$ of soil organic carbon has a turnover time ranging between 1 and 20 years. Harrison et al. [1993] indicate that $50 \%$ of the soil column contains fast-cycling carbon and estimate the global fast-cycling pool to be $500 \mathrm{Pg} \mathrm{C}$ with components that have resident times ranging from 10 to 100 years. Trumbore et al. [1996] demonstrate fast tumover ( 7 to 65 years) for 50 to $90 \%$ of carbon in the upper $20 \mathrm{~cm}$ of soil. In the upper $20 \mathrm{~cm}$ of soil, the Century model estimates that approximately $10 \%$ of the soil organic pool is represented in the soil microbial and detrital pools with 0 - to 10 -year turnover, approximately $50 \%$ is represented in a slow pool with 20 - to 100 -year turnover, and approximately $40 \%$ is represented in a passive pool with 1000 - to 5000-year turnover [Schimel et al., 1994]. On the basis of the 837.2 Pg C estimated by the third version of TEM for organic carbon stocks in the upper $20 \mathrm{~cm}$ of soil [Melillo et al., 1995] and the $60 \%$ estimate of soil carbon with 0 - to 100 -year tumover, $502 \mathrm{Pg} \mathrm{C}$ of global soil carbon stocks has 0 - to 100-year turnover, which agrees closely with the $500 \mathrm{Pg} \mathrm{C}$ estimate of Harrison et al. [1993]. On the basis of these estimates, we interpret that the $771.7 \mathrm{Pg} \mathrm{C}$ pool estimated by TEM represents soil carbon with turnover times minimally in the range from 0 to 100 years and perhaps to several hundred years, but that the pool excludes soil carbon with millenial turnover. Therefore we feel that TEM minimally characterizes the decadal response of soil carbon up to about a century, which is an appropriate timescale for considering potential terrestrial responses to doubled atmospheric $\mathrm{CO}_{2}$. The model may characterize soil carbon responses beyond a century, but the timescale depends on what fraction of soil carbon with 100- to 1000 -year turnover is represented by the model; soil reservoirs with 400 -year turnover may start to dominate soil carbon responses to rising atmospheric $\mathrm{CO}_{2}$ after about 100 years [Sarmiento et al., 1995].

In contrast to NPP, global carbon storage has a bimodal latitudinal distribution, with substantial carbon storage in both the equatorial and boreal regions (Figure 2b). Vegetation carbon accounts for most of the storage in the tropics (Figure 2b); $74.5 \%$ of the carbon in tropical evergreen forest is stored in vegetation (Table 1). In contrast, soil carbon accounts for more than half of the storage in the boreal region (Figure $2 \mathrm{~b}$ ); $53.9 \%$ of the carbon in boreal forest is stored in soils (Table 1). Because higher temperature causes soil organic matter to decompose at a higher rate, temperature is the most important variable determining the latitudinal pattern of the contribution of soil carbon to total carbon storage, although soil moisture also plays a role [see McGuire et al., 1995b].

\section{Reference Responses of NPP and Carbon Storage}

In response to doubled atmospheric $\mathrm{CO}_{2}$, TEM estimates that global NPP increases 4.1 $\mathrm{Pg} \mathrm{C} \mathrm{yr}^{-1}$ (Table 2), which is a relative increase of $8.3 \%$. Much of the NPP response is concentrated in the tropics where tropical evergreen forest accounts for $32.8 \%$ of the global response (Figure 3a). The latitudinal distribution of response broadly extends throughout the northern and southem temperate regions (Figure 3a), where temperate forests account for $14.3 \%$ of the response (Table 2). Although the relative NPP responses of deserts (36.0\% increase) and arid shrublands (24.3\% increase) are high, these ecosystems account for only $12.5 \%$ of the global response (Table 2) because of their low productivity. The latitudinal distribution of NPP response drops off substantially between the temperate and polar regions (Figure 3a) where high-latitude ecosystems account for only $3.5 \%$ of the global response (Table 2).

For doubled atmospheric $\mathrm{CO}_{2}$, the estimate of global total carbon storage by TEM increases $114.2 \mathrm{Pg} \mathrm{C}$ (Table 2). Soil carbon accounts for $41.7 \%$ of the increased carbon storage, and vegetation carbon accounts for $58.3 \%$ (Table 2). The latitudinal 


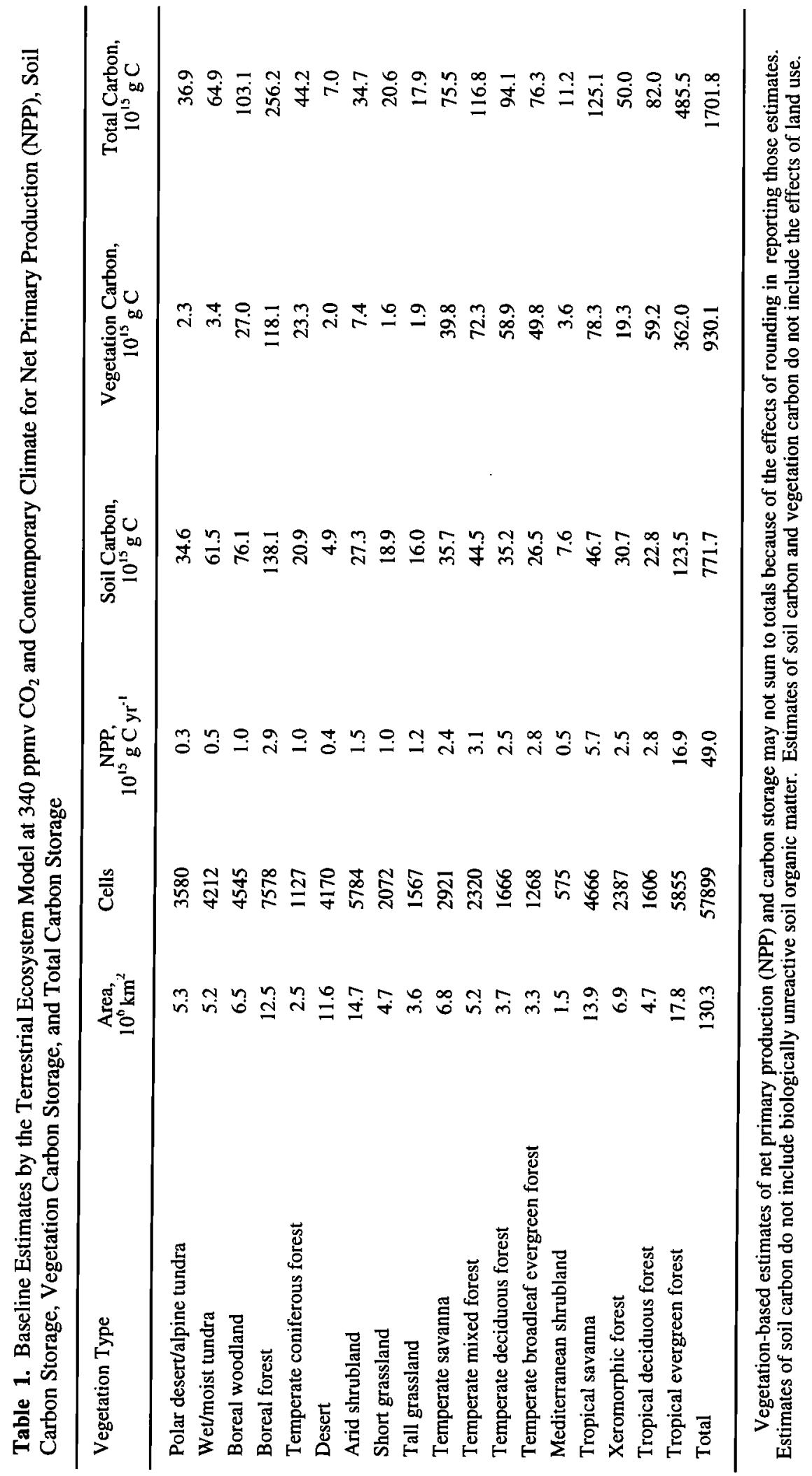



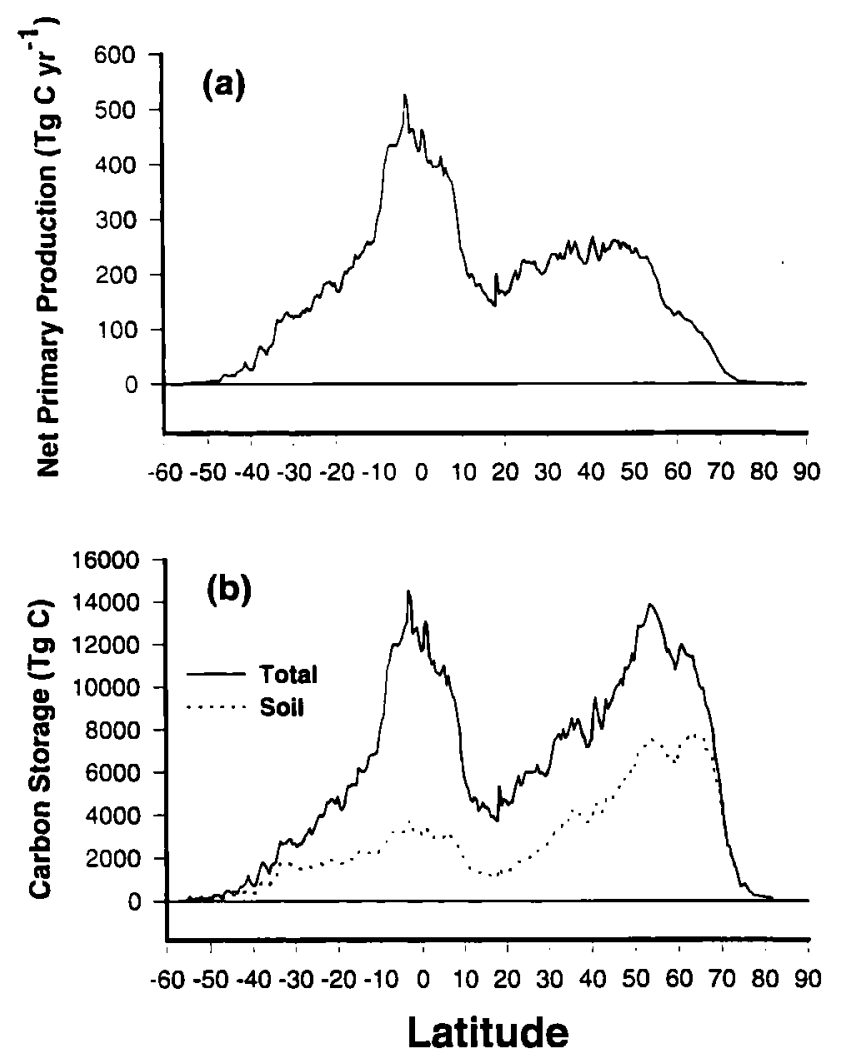

Figure 2. Latitudinal distributions for the baseline estimates of (a) net primary production and (b) carbon storage by the Terrestrial Ecosystem Model at $340 \mathrm{ppmv} \quad \mathrm{CO}_{2}$ and contemporary climate. Estimates of soil carbon do not include biologically unreactive soil organic matter. The resolution of NPP and carbon storage is $0.5^{\circ}$ latitude.

distribution of the total carbon response is more bimodal than the NPP response with peaks in the tropics near the equator and in the north temperate zone (Figure $3 \mathrm{~b}$ ). The peak in the equatorial tropics is caused primarily by a peak in the response of vegetation carbon, which accounts for $75.0 \%$ of the increased carbon storage in tropical evergreen forest. The peak in the north temperate zone is caused by peaks in the responses of both vegetation and soil carbon. In contrast, in high-latitude regions, the response of soil carbon increasingly accounts for more of the total carbon response as latitude approaches the poles (Figure 3b). For example, soil carbon accounts for $49.3 \%$ of the response in boreal forest, $70.8 \%$ of the response in boreal woodland, and $92.6 \%$ of the response in tundra and polar desert.

\section{Sensitivity of NPP and Carbon Storage Responses to Changes in Plant Nitrogen Concentration}

For simulations in which lower vegetation nitrogen concentration is uncoupled from decomposition dynamics (lower $\mathbf{N}$ ), the response of global NPP to doubled atmospheric $\mathrm{CO}_{2}$ increases approximately $2 \mathrm{Pg} \mathrm{C} \mathrm{yr}{ }^{-1}$ for each incremental $7.5 \%$ reduction in vegetation nitrogen concentration (Figure 4a). The response of NPP causes larger increases in both vegetation and soil carbon for greater reductions in nitrogen concentration
(Figures $4 \mathrm{~b}$ and $4 \mathrm{c}$ ). For each $7.5 \%$ reduction in nitrogen concentration, the response of vegetation carbon increases approximately an additional $40 \mathrm{Pg} \mathrm{C}$ and soil carbon an additional $30 \mathrm{Pg} \mathrm{C}$. The responses of vegetation and soil carbon combine so that total carbon storage increases approximately an additional $70 \mathrm{Pg} \mathrm{C}$ for each $7.5 \%$ reduction in nitrogen concentration (Figure 4d).

For simulations in which lower vegetation nitrogen concentration is coupled with decomposition dynamics (lower N+D), the response of NPP is relatively insensitive to differences in the reduction of nitrogen concentration (Figure 4a). The NPP increase is $5.0{\mathrm{Pg} \mathrm{C} \mathrm{yr}^{-1}}$ for a $22.5 \%$ reduction compared with a 4.1 $\mathrm{Pg} \mathrm{C}_{\mathrm{yr}}^{-1}$ increase for no reduction. The insensitivity in the coupled simulations occurs because potential enhancements in NPP associated with reduced vegetation nitrogen concentration are approximately offset by lower nitrogen availability associated with the decomposition dynamics of reduced litter nitrogen concentration. Because of this insensitivity, the response of vegetation carbon storage is also insensitive to reductions in vegetation nitrogen concentration (Figure $4 b$ ). For a $22.5 \%$ reduction in nitrogen concentration, vegetation carbon increases 83.3 Pg C compared with 66.6 Pg C for no change in nitrogen concentration. In contrast, the response of soil carbon storage is larger for greater reductions in nitrogen concentration (Figure 4c). Lower nitrogen concentration of litter input to the soil slows decomposition so that for each $7.5 \%$ reduction in vegetation nitrogen concentration, soil carbon increases approximately an additional $60 \mathrm{Pg} \mathrm{C}$ (Figure $4 \mathrm{c}$ ). The responses of vegetation and soil carbon storage combine so that total carbon storage increases approximately $65 \mathrm{Pg} \mathrm{C}$ for each $7.5 \%$ reduction in nitrogen concentration (Figure 4d). Thus, for simulations in which reductions in nitrogen concentration are coupled with decomposition dynamics, the global sensitivity of total carbon storage to reductions in nitrogen concentration is similar to that for simulations in which reductions are uncoupled from decomposition dynamics. Although the global sensitivity is similar, the response of soil carbon is more important in the coupled simulations. This has implications for the latitudinal distributions of carbon storage responses.

For the simulations in which changes in vegetation nitrogen concentration are uncoupled from decomposition dynamics, the latitudinal distribution of NPP response is sensitive to reductions in nitrogen concentration throughout the terrestrial biosphere (Figure 5a) but is insensitive for the coupled simulations (Figure $5 b$ ). Thus, in the coupled simulations, potential enhancements in NPP associated with reduced vegetation nitrogen concentration are approximately offset by lower nitrogen availability associated with the decomposition dynamics of reduced litter quality. The latitudinal sensitivity of NPP response causes a similar pattern in the response of vegetation carbon where the latitudinal distribution is sensitive to the reduction of nitrogen concentration in the uncoupled simulations (Figure 6a) but is insensitive in the coupled simulations (Figure 6b). In contrast, the latitudinal distribution of soil carbon response is sensitive to reductions in nitrogen concentration for both the uncoupled simulations (Figure 7a) and the coupled simulations (Figure 7b). Throughout the terrestrial biosphere, the response of soil carbon is more sensitive for the coupled simulations because of the decomposition dynamics associated with lower litter quality. In both sets of simulations, the response of soil carbon is substan- 


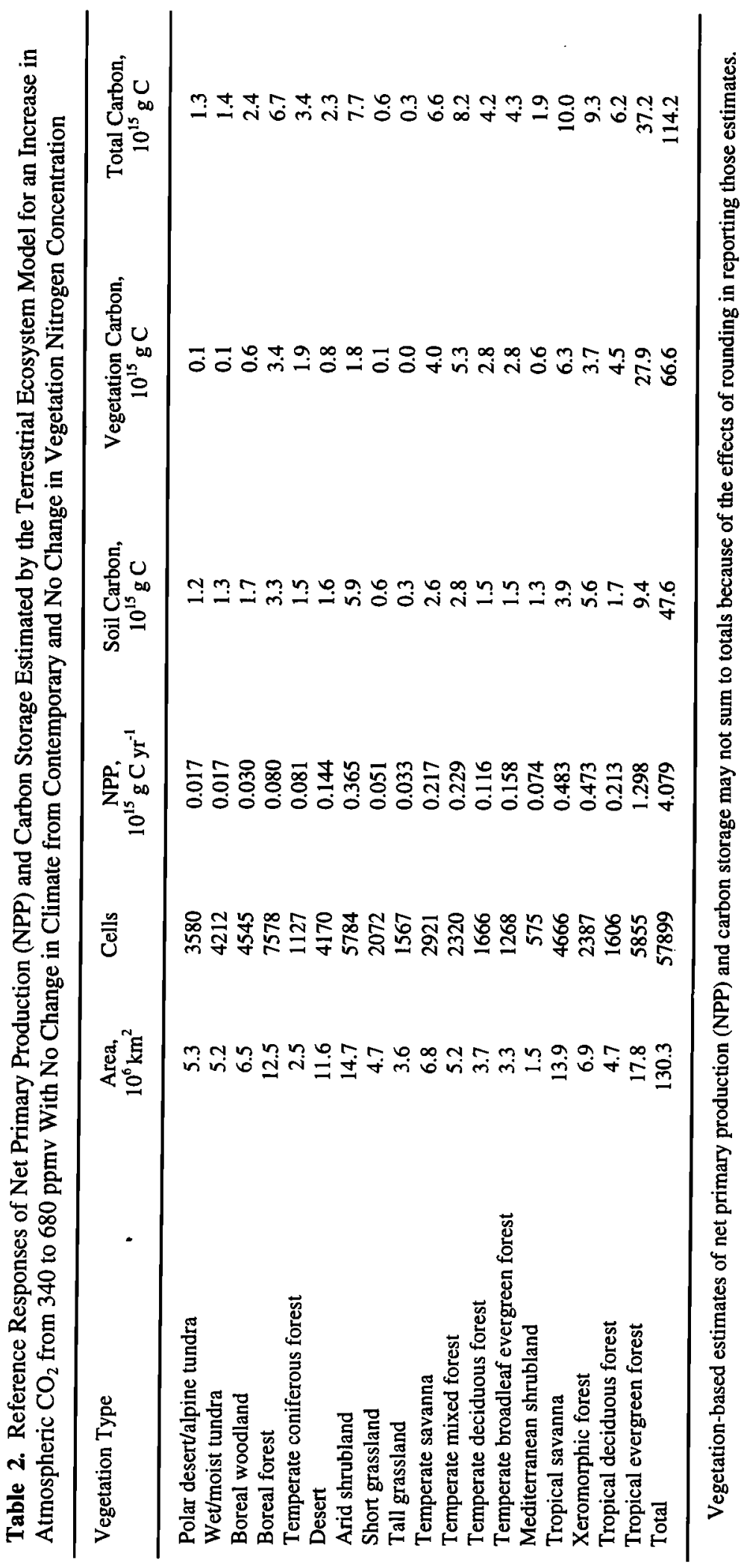



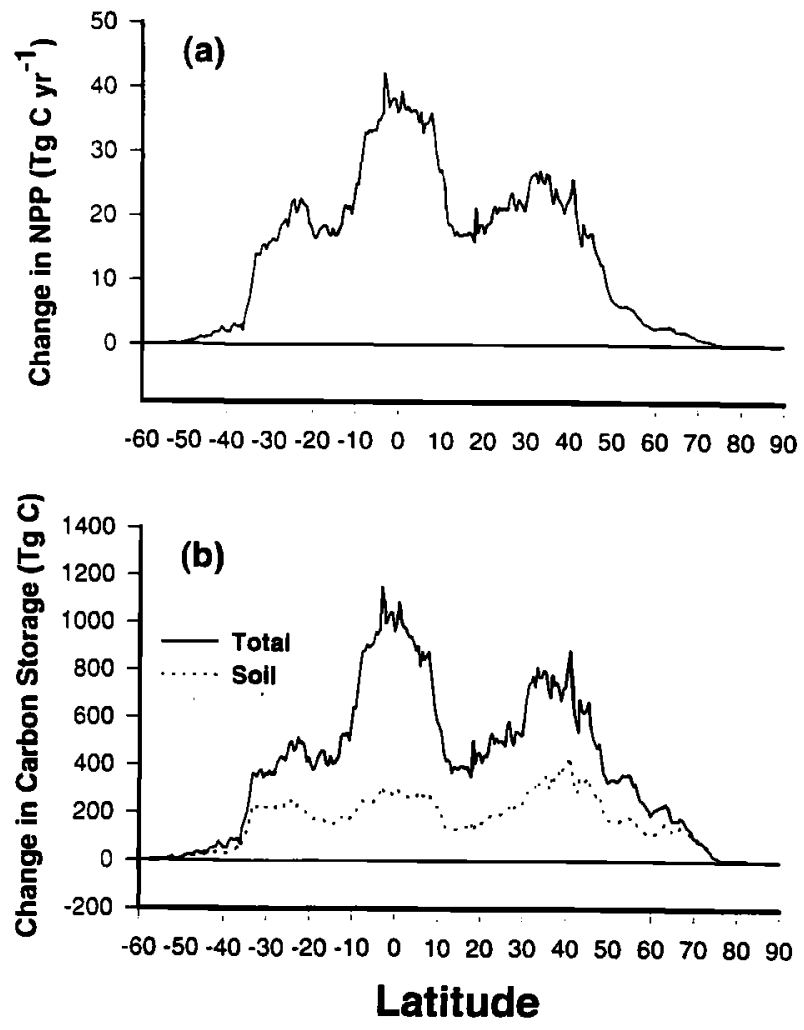

Figure 3. Latitudinal distributions for the reference response of (a) net primary production (NPP) and (b) carbon storage estimated by the Terrestrial Ecosystem Model for an increase in atmospheric $\mathrm{CO}_{2}$ from 340 to $680 \mathrm{ppmv}$ with no change in climate from contemporary and no change in vegetation nitrogen concentration. The resolution of NPP and carbon storage responses is $0.5^{\circ}$ latitude.

tially more sensitive in temperate and boreal regions than in the tropics. The combined responses of vegetation and soil carbon indicate that the response of total carbon storage in both sets of simulations is bimodally distributed between the tropics and the north temperate-boreal region (Figures $8 \mathrm{a}$ and $8 \mathrm{~b}$ ). As the reduction in vegetation nitrogen concentration gets greater in the coupled simulations, more of the additional carbon storage tends to become concentrated in the north temperate-boreal region in comparison to the tropics (Figure 8b). Also, the additional carbon storage in the north temperate-boreal region tends to shift more northward for greater reductions in nitrogen concentration.

\section{Discussion}

\section{Baseline Estimates of NPP and Carbon Storage}

The estimate of global annual NPP by TEM 4.0 in this study for baseline atmospheric $\mathrm{CO}_{2}(49.0 \mathrm{Pg} \mathrm{C})$ is similar to many of the estimates that have appeared in the literature (mean $53.1 \mathrm{Pg}$ $\mathrm{C} ; \mathrm{N}=13$; range 40.5 Pg C to 78.0 Pg C; standard deviation 9.3 Pg C [see Melillo et al., 1993]). This estimate is slightly higher than the 47.9 $\mathrm{Pg} \mathrm{C} \mathrm{yr}^{-1}$ reported by Xiao et al. [1997] in which TEM 4.0 was applied with the same climate, soils, and vegetation inputs at an atmospheric $\mathrm{CO}_{2}$ concentration of $315 \mathrm{ppmv}$.
The global NPP estimate also differs from the $53.2 \mathrm{Pg} \mathrm{C}$ reported by Melillo et al. [1993], which used a different version of TEM (version 3), different input data sets, different terrestrial boundaries associated with the input data sets, and a different level of baseline $\mathrm{CO}_{2}$. Although the global totals of the two applications differ, both are within the range of estimates reported in the literature, and both applications report similar distributions of NPP among terrestrial ecosystems. For example, the $34.5 \%$ of global NPP in tropical evergreen forest in the baseline simulation of this study is similar to the $35.9 \%$ reported by Melillo et al. [1993]. Similarly, 2.4\% of global NPP in the three least productive ecosystems is similar to the $3.0 \%$ reported by Melillo et al. [1993]. The sensitivity of annual NPP estimates by TEM 4.0 to different alternative input data sets of temperature, precipitation, solar radiation, and soil texture has been evaluated by Pan et al. [1996].

Similar to NPP, the baseline estimates of carbon storage are slightly higher than those reported by Xiao et al. [1997], in which TEM 4.0 estimated global terrestrial carbon storage to be $1659 \mathrm{Pg} \mathrm{C}$, with $909 \mathrm{Pg} \mathrm{C}$ in vegetation and $750 \mathrm{Pg} \mathrm{C}$ in soils. The estimate of soil carbon storage is also different from that reported by $M c G$ uire et al. [1995b], in which TEM 4.0 estimated global soil carbon storage of $706.5 \mathrm{Pg} \mathrm{C}$. The application of TEM by McGuire et al. [1995b] used different input data sets, different terrestrial boundaries associated with the input data sets, and a different level of baseline $\mathrm{CO}_{2}(312.5$ ppmv). Differences between the global estimates of vegetation carbon storage in this study (930.1 Pg C) and the $977 \mathrm{Pg} \mathrm{C}$ reported by the application of version 3 of TEM in Melillo et al. [1995] are largely related to differences in NPP estimates. Differences in soil carbon storage between versions 3 and 4 of TEM largely depend on whether unreactive soil organic matter has been included in the estimates [see McGuire et al., 1995b; Melillo et al., 1995].

\section{The Reference Responses of NPP and Carbon Storage}

The $8.3 \%$ increase of global NPP in the reference simulation of doubled $\mathrm{CO}_{2}$ response is similar in magnitude to the $9 \%$ response of TEM 4.0 , the $11 \%$ response of Biome-BGC (for Biome BioGeoChemical Cycles), and the $5 \%$ response of Century in equilibrium doubled $\mathrm{CO}_{2}$ simulations for the conterminous United States in the Vegetation/Ecosystem Modeling and Analysis Project (VEMAP) [see VEMAP Members, 1995]. All of these responses are substantially lower than the 25 to $50 \%$ response observed among studies that provide adequate nutrients and water to experimental plants [Kimball, 1975; Gates, 1985]. Although the models tend to agree on the magnitude of continental-scale NPP responses to doubled atmospheric $\mathrm{CO}_{2}$, different factors constrain the response of NPP [Pan et al., 1995]. All the models agree that relative NPP tends to increase along gradients of decreasing precipitation. However, along gradients of decreasing temperature, estimates of relative NPP responses tend to decrease for TEM, increase for Biome-BGC, and have no pattern for Century [Pan et al., 1995]. For TEM simulations, the spatial patterns and magnitude of NPP responses in the reference simulations of doubled $\mathrm{CO}_{2}$ response represent interactions of carbon, water, and nitrogen dynamics in the formulations of ecosystem processes in the model.

The magnitude of the NPP response is limited in the TEM simulations because the availability of nitrogen constrains the 

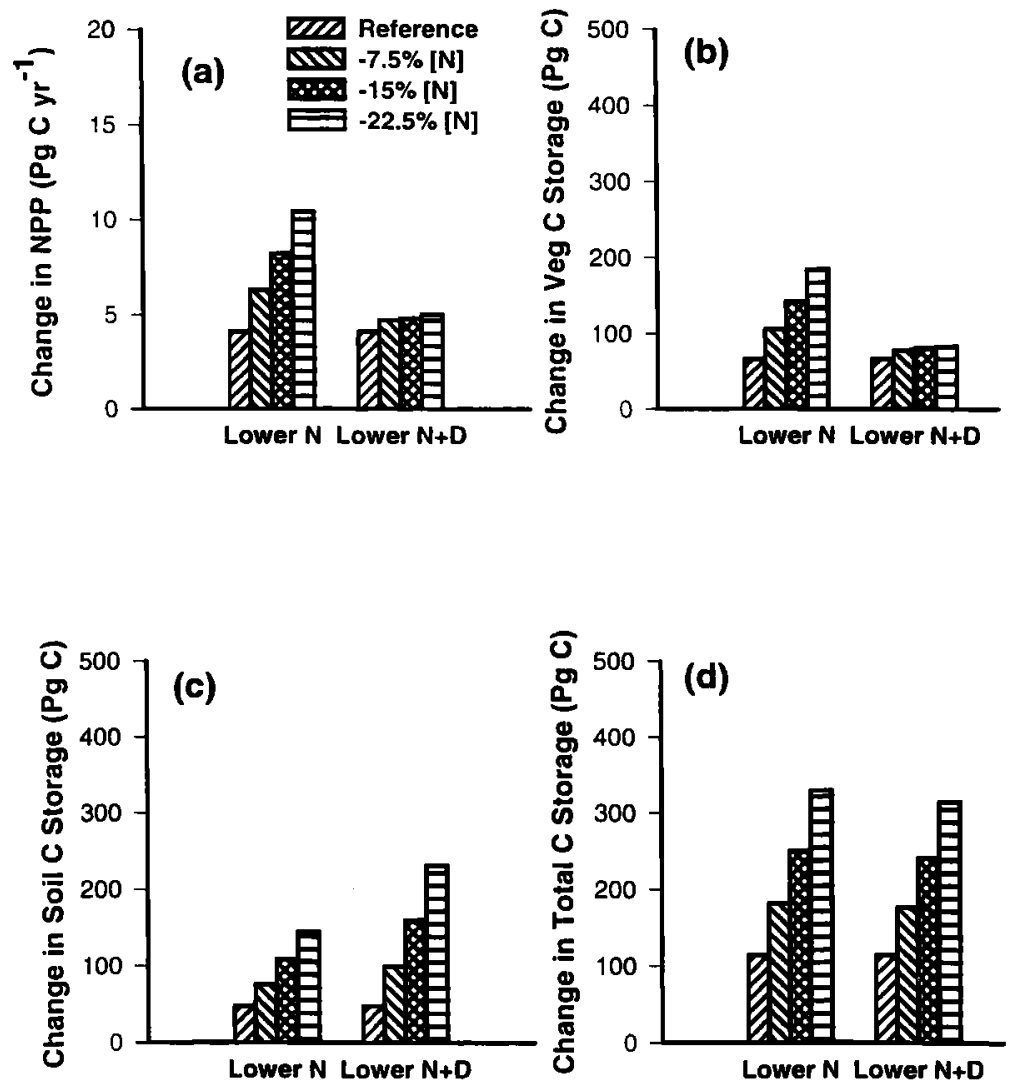

Figure 4. Sensitivity to $7.5,15.0$, and $22.5 \%$ decreases in vegetation nitrogen concentration for the global responses of (a) net primary production (NPP), (b) vegetation carbon storage, (c) soil carbon storage, and (d) total carbon storage estimated by the Terrestrial Ecosystem Model for a change in atmospheric $\mathrm{CO}_{2}$ from 340 to $680 \mathrm{ppmv}$ with no change in climate from contemporary. Sensitivity is shown for simulations in which vegetation nitrogen concentration is uncoupled from decomposition dynamics (Lower $\mathrm{N}$ ) and coupled to decomposition dynamics (Lower $\mathrm{N}+\mathrm{D}$ ). The reference responses for no change in vegetation nitrogen concentration are shown for comparison.

response of plant growth to elevated $\mathrm{CO}_{2}$ for much of the terrestrial biosphere. In environments with adequate soil moisture, TEM estimates that production is less limited by nitrogen availability in warmer environments because of a closer match between potential carbon assimilation and carbon assimilation that can be supported by nitrogen cycling [McGuire et al., 1992, 1993]. Because temperature plays an important role in the availability of nitrogen estimated by TEM, relative NPP responses in moist environments tend to be highest in the tropics, intermediate in the temperate zone, and lowest in high-latitude regions. The model estimates that low nitrogen availability associated with cold soils substantially limits the ability of vegetation in high-latitude ecosystems to incorporate elevated $\mathrm{CO}_{2}$ into production [see also McGuire et al., 1993; Melillo et al., 1993]. In comparison to moist environments, TEM estimates that the relative NPP response is substantially higher in deserts and arid shrublands because the response of $f\left(C_{a}, G_{v}\right)$ to doubled $\mathrm{CO}_{2}$ is higher in dry environments and nitrogen availability is not as important as water availability in limiting production in these ecosystems. Although changes in vegetation carbon in the reference simulation of doubled $\mathrm{CO}_{2}$ response have a similar spatial pattern to changes in NPP, the spatial pattern of soil carbon response estimated by TEM is different.
Similar to NPP, the $6.7 \%$ increase of global carbon storage in the reference simulation of doubled $\mathrm{CO}_{2}$ response is similar in magnitude to the $9 \%$ response of TEM 4.0 , the $7 \%$ response of Biome-BGC, and the $2 \%$ response of Century in equilibrium doubled $\mathrm{CO}_{2}$ simulations for the conterminous United States [VEMAP Members, 1995]. The partitioning between increases in global vegetation and carbon storage by TEM in this study (58.3\% in vegetation) is similar to the range of partitioning estimated among the models in the VEMAP study (57 to $67 \%$ in vegetation). For the TEM simulations, the relative responses of vegetation carbon storage are similar both in magnitude and spatial pattern to the NPP responses. Because of the temperature sensitivity of decomposition in TEM, the portion of the total carbon response accounted for by increases in soil carbon are highest in high-latitude regions, intermediate in the temperate zone, and lowest in the tropics. Because TEM estimates much of the global NPP response to doubled $\mathrm{CO}_{2}$ is concentrated in the tropics, increases in global vegetation carbon storage tend to be higher than increases in soil carbon storage in the model simulations.

Although numerous experimental studies have investigated tissue and plant responses to elevated $\mathrm{CO}_{2}$ [Kimball, 1975; Kimball and Idso, 1983; Eamus and Jarvis, 1989; Poorter, 


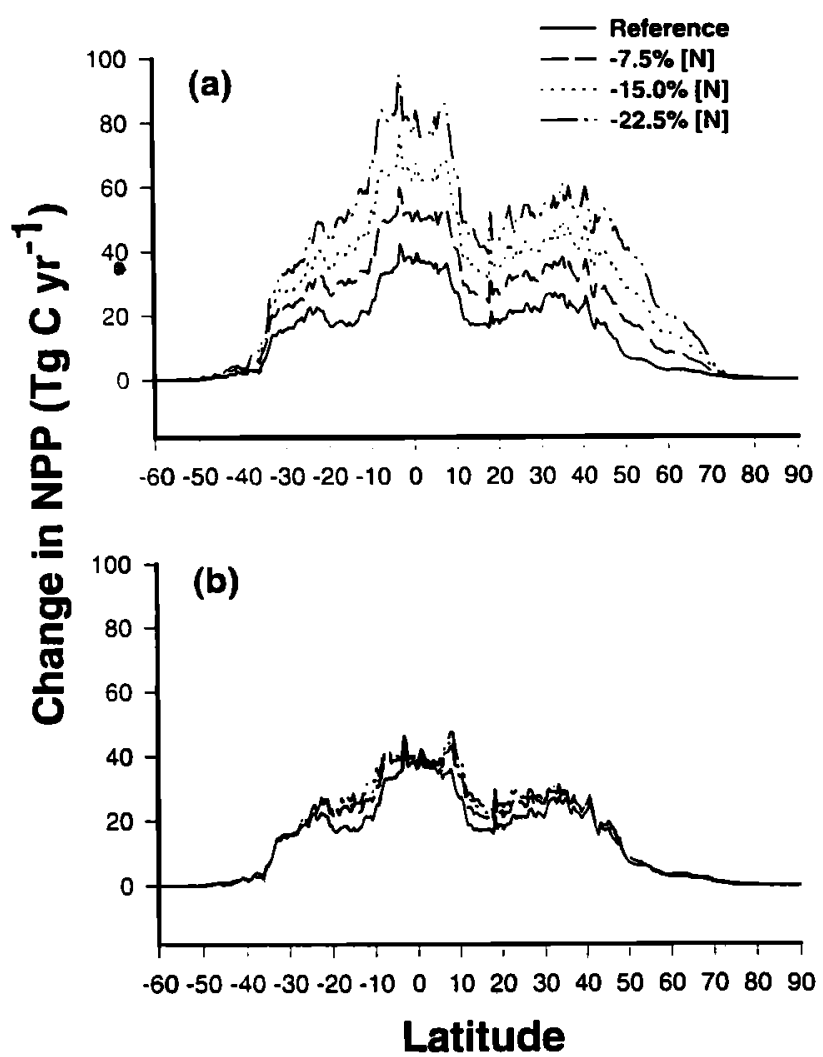

Figure 5. Sensitivity to $7.5,15.0$, and $22.5 \%$ decreases in vegetation nitrogen concentration for the latitudinal distributions of NPP responses to doubled $\mathrm{CO}_{2}$ as estimated by the Terrestrial Ecosystem Model for simulations in which changes in vegetation nitrogen concentration are (a) uncoupled from decomposition dynamics and (b) coupled to decomposition dynamics. The doubled $\mathrm{CO}_{2}$ responses are for a change in atmospheric $\mathrm{CO}_{2}$ from 340 to $680 \mathrm{ppmv}$ with no change in climate from contemporary. The latitudinal distribution of the reference NPP response for no change in vegetation nitrogen concentration is shown for comparison. The resolution of NPP responses is $0.5^{\circ}$ latitude.

1993; Ceulemans and Mousseau, 1994; Idso and Idso, 1994; McGuire et al., 1995a; Wullschleger et al., 1995], there are only a handful of studies that document ecosystem-level responses to elevated $\mathrm{CO}_{2}$ [Mooney et al., 1991; McGuire et al., 1995a]. Because ecosystem-level responses of NPP and carbon storage to elevated $\mathrm{CO}_{2}$ have been poorly documented, the controls over the response are poorly understood. Among spatially explicit biogeochemical models, this lack of understanding has led to different conceptualizations about how ecosystem processes control the response of NPP and carbon storage to elevated $\mathrm{CO}_{2}$. The conceptualization and formulations in TEM and other models represent a range of empirical findings observed in various field and laboratory studies but do not encompass the full range of environmental and ecosystem conditions that are simulated in continental- and global-scale studies of terrestrial responses to elevated $\mathrm{CO}_{2}$ (Y. Pan et al., unpublished manuscript, 1997). Although our experimental understanding is poor, spatially explicit biogeochemical models like TEM are useful tools for exploring the potential consequences of uncer-

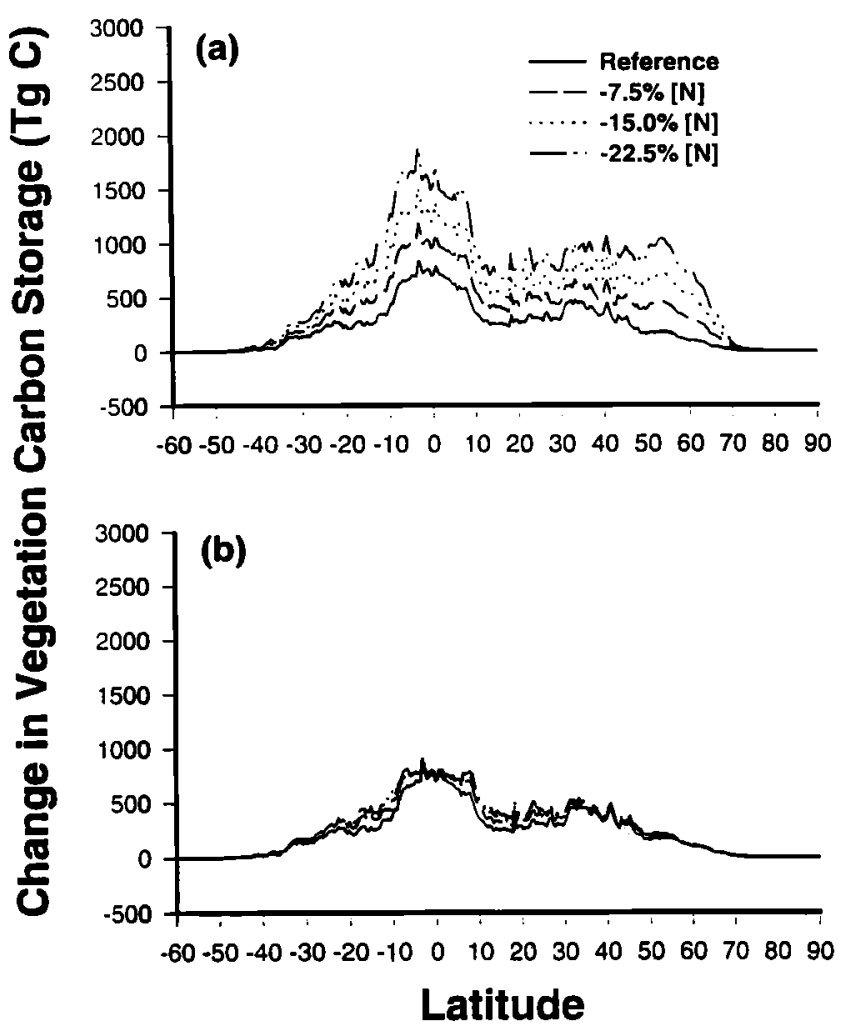

Figure 6. Sensitivity to $7.5,15.0$, and $22.5 \%$ decreases in vegetation nitrogen concentration for the latitudinal distributions of vegetation carbon responses to doubled $\mathrm{CO}_{2}$ as estimated by the Terrestrial Ecosystem Model for simulations in which changes in vegetation nitrogen concentration are (a) uncoupled from decomposition dynamics and (b) coupled to decomposition dynamics. The doubled $\mathrm{CO}_{2}$ responses are for a change in atmospheric $\mathrm{CO}_{2}$ from 340 to $680 \mathrm{ppmv}$ with no change in climate from contemporary. The latitudinal distribution of the reference response of vegetation carbon for no change in vegetation nitrogen concentration is shown for comparison. The resolution of carbon storage responses is $0.5^{\circ}$ latitude.

tainty in biospheric responses to global change. One of these uncertainties involves the influence of changes in vegetation nitrogen concentration on the responses of NPP and carbon storage to increases in atmospheric $\mathrm{CO}_{2}$.

\section{Sensitivity of NPP and Carbon Storage Responses to Changes in Plant Nitrogen Concentration}

The global responses of NPP and vegetation carbon storage for the simulations in which lower vegetation nitrogen concentration is coupled with decomposition dynamics are relatively insensitive to changes in vegetation nitrogen concentration (increases of 4 versus $5 \mathrm{Pg} \mathrm{C}$ ). The insensitivity occurs because enhancements attributable to reduced nitrogen concentration of the vegetation are approximately offset by decreases attributable to reduced litter quality and slower decomposition rates. In contrast, the responses of total carbon storage are sensitive to the feedback associated with changes in vegetation nitrogen concentration (increases range from $100 \mathrm{Pg} \mathrm{C}$ for no change to 


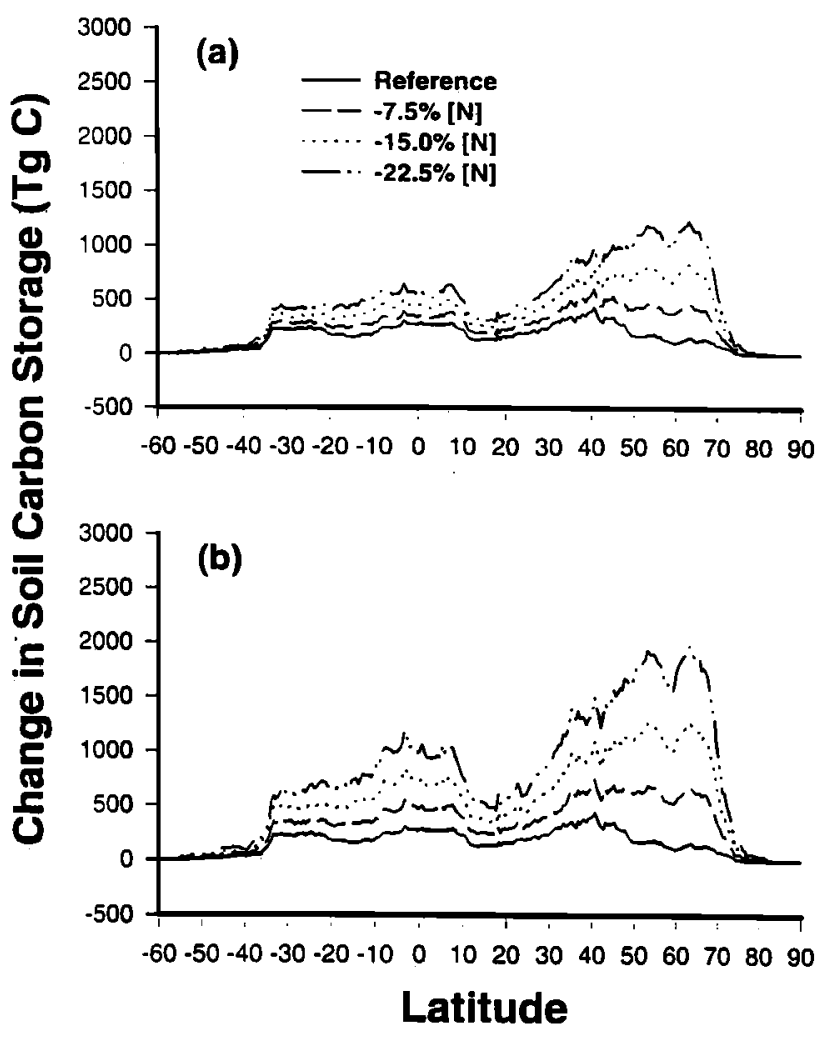

Figure 7. Sensitivity to $7.5,15.0$, and $22.5 \%$ decreases in vegetation nitrogen concentration for the latitudinal distributions of soil carbon responses to doubled $\mathrm{CO}_{2}$ as estimated by the Terrestrial Ecosystem Model for simulations in which changes in vegetation nitrogen concentration are (a) uncoupled from decomposition dynamics and (b) coupled to decomposition dynamics. The doubled $\mathrm{CO}_{2}$ responses are for a change in atmospheric $\mathrm{CO}_{2}$ from 340 to $680 \mathrm{ppmv}$ with no change in climate from contemporary. The latitudinal distribution of the reference response of soil for no change in vegetation nitrogen concentration is shown for comparison. The resolution of carbon storage responses is $0.5^{\circ}$ latitude.

$330 \mathrm{Pg} \mathrm{C}$ for a $22.5 \%$ decrease). For each $7.5 \%$ reduction in vegetation nitrogen concentration, soil carbon increases approximately an additional $60 \mathrm{Pg} \mathrm{C}$, while vegetation carbon storage increases by only approximately $5 \mathrm{Pg} \mathrm{C}$. Thus greater carbon storage is caused primarily by increased soil carbon storage associated with lower decomposition rates and secondarily by increased vegetation carbon storage associated with lower vegetation nitrogen concentration. In temperate and boreal regions, the responses of soil carbon storage to changes in vegetation nitrogen concentration are more sensitive than in the tropics because reduced litter quality causes carbon to accumulate in soils more at low temperature than at high temperature. Thus the response of vegetation nitrogen dynamics to elevated atmospheric $\mathrm{CO}_{2}$ and the coupling of those dynamics with the dynamics of decomposition has potential consequences for the both the nature and spatial pattern of carbon storage responses in the terrestrial biosphere.

Although numerous experimental studies have investigated the role of nitrogen in leaf- and plant-level responses of carbon uptake to elevated $\mathrm{CO}_{2}$, our knowledge of how $\mathrm{CO}_{2}$-induced

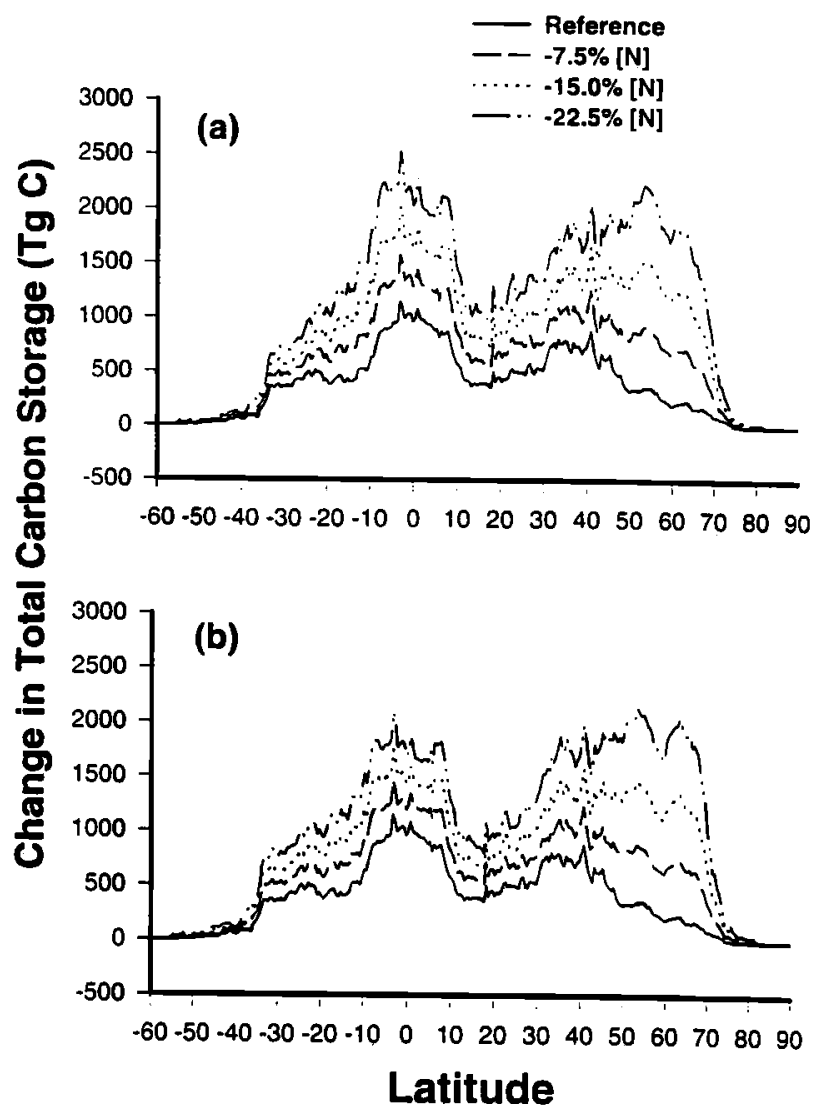

Figure 8. Sensitivity to $7.5,15.0$, and $22.5 \%$ decreases in vegetation nitrogen concentration for the latitudinal distributions of total carbon responses to doubled $\mathrm{CO}_{2}$ as estimated by the Terrestrial Ecosystem Model for simulations in which changes in vegetation nitrogen concentration are (a) uncoupled from decomposition dynamics and (b) coupled to decomposition dynamics. The doubled $\mathrm{CO}_{2}$ responses are for a change in atmospheric $\mathrm{CO}_{2}$ from 340 to $680 \mathrm{ppmv}$ with no change in climate from contemporary. The latitudinal distribution of the reference response of total carbon for no change in vegetation nitrogen concentration is shown for comparison. The resolution of carbon storage responses is $0.5^{\circ}$ latitude.

changes in plant nitrogen concentration influence carbon cycling at the ecosystem level is based on a small number of studies [see McGuire et al., 1995a]. At present, the available data suggest that $\mathrm{CO}_{2}$-induced reductions in litter quality may depress decomposition rates, but the data are ambiguous. Effects on nitrogen mineralization are less well documented. Additional experimental research is required at the ecosystem level to understand how interactions of the nitrogen cycle and elevated $\mathrm{CO}_{2}$ affect NPP and carbon storage.

To our knowledge, this is the first study to report how potential changes in vegetation nitrogen concentration may influence the $\mathrm{CO}_{2}$ response of global terrestrial carbon storage in a geographically specific manner. The sensitivity analysis reported in this study is in the context of TEM, which is a generalized abstraction of processes that influence carbon cycling in terrestrial ecosystems at large spatial scales. The structure of TEM is highly aggregated both for computational efficiency and for 
parsimonious representation of processes that are incompletely understood at large spatial scales. Because TEM is a highly aggregated model, it does not explicitly represent canopy development and tissue nitrogen concentration. Although vegetation nitrogen concentration, canopy development, and photosynthesis are implicitly coupled in the model, we do not know if the global and regional sensitivity of carbon cycling to changes in nitrogen concentration would be altered by more explicit representations of vegetation structure and development. A comparison of the results in this study to similar simulations by models that explicitly represent the tradeoff between canopy development and the acclimation response of tissue-level photosynthesis would help determine if the structure of TEM should be less aggregated.

The sensitivity analysis reported in this study is also in the context of a closed nitrogen cycle. Globally, the natural terrestrial nitrogen cycle may be approximately balanced with an estimated $16010^{12} \mathrm{~g}(\mathrm{Tg}) \mathrm{N} \mathrm{yr}^{-1}$ entering terrestrial ecosystems in nitrogen fixation and leaving terrestrial ecosystems in river flow and denitrification [Schlesinger, 1991]. Although the natural nitrogen cycle may be approximately balanced, nitrogen released from fossil fuel burning deposits between 50 and $80 \mathrm{Tg}$ $\mathrm{N} \mathrm{yr}{ }^{-1}$ globally, with approximately $20 \mathrm{Tg} \mathrm{N} \mathrm{yr}^{-1}$ deposited on temperate and boreal forests of North America and Europe [Melillo et al., 1996a]. Experimental evidence suggests that the interaction between elevated $\mathrm{CO}_{2}$ and nitrogen deposition may have important implications for forest growth in regions of the world that receive substantial inputs of anthropogenic nitrogen from the atmosphere [see McGuire et al., 1995a]. Several efforts in the international biogeochemical science community are attempting to organize spatially explicit data sets of nitrogen deposition for both the terrestrial and oceanic components of the biosphere. Once these data are available, terrestrial biogeochemical models like TEM will be able to conduct analyses that investigate how the interaction between fossil fuel burning, rising levels of atmospheric $\mathrm{CO}_{2}$, and anthropogenic nitrogen deposition may influence terrestrial carbon storage.

\section{Conclusion}

During the next century, substantial simultaneous changes are expected to occur in a variety of environmental variables including atmospheric $\mathrm{CO}_{2}$, temperature, precipitation, cloudiness, and atmospheric deposition of nutrients [Melillo et al., 1989b; Mitchell et al., 1990; Watson et al., 1992]. Also, human activity is substantially altering the vegetation of the terrestrial biosphere [Houghton et al., 1983, 1991; Melillo et al., 1988; Houghton and Skole, 1990; Myers, 1991; Melillo et al., 1996b]. Our purpose in this study is not to define terrestrial responses to global change but to assess whether the coupling between vegetation nitrogen dynamics and decomposition dynamics has potential consequences for the global carbon cycle. In the context of TEM, our analyses indicate that inclusion of these processes has consequences not only for carbon cycle responses to elevated atmospheric $\mathrm{CO}_{2}$ but also for climate change that may accompany rising levels of $\mathrm{CO}_{2}$. For climate changes without changes in atmospheric $\mathrm{CO}_{2}$, previous simulations with TEM indicate that global NPP is relatively insensitive and that total carbon storage decreases [Melillo et al., 1993, 1995; McGuire et al., 1996]. However, when climate change is accompanied by doubled atmospheric $\mathrm{CO}_{2}$, TEM estimates that the effects of elevated $\mathrm{CO}_{2}$ more than offset the effects of climate change to cause increased carbon storage [Melillo et al., 1993, 1995; McGuire et al., 1996]. The results of this study indicate that carbon storage would be further enhanced by consideration of the influence of changes in plant nitrogen concentration on carbon assimilation and decomposition rates. Thus, the influence of changes in vegetation nitrogen concentration may have important implications for the ability of the terrestrial biosphere to mitigate increases in the atmospheric concentration of $\mathrm{CO}_{2}$ and climate changes associated with the increases.

Acknowledgments. We thank Jorge Sarmiento, David Schimel, and four anonymous reviewers for thoughtful comments on earlier drafts of this paper. This study was funded by the Earth Observing System Program of the National Aeronautics and Space Administration (NAGW-2669) and the Electric Power Research Institute.

\section{References}

Aber, J. D., J. M. Melillo, and C. A. Federer, Predicting the effects of rotation length, harvest intensity, and fertilization on fiber yield from northern hardwood forests in New England, For. Sci., 28, 31-48, 1982.

Agren, G.I., The interaction between $\mathrm{CO}_{2}$ and plant nutrition: Comments on a paper by Coleman, McConnaughay and Bazzaz, Oecologia, 98, 239-240, 1994.

Auchmoody, L. R., and H. C. Smith, Responses of yellow-poplar and red oak to fertilization in West Virginia, Soil Sci. Am. J., 41, 803807, 1977.

Bartholomew, M. V., and A. G. Norman, The threshold moisture content for active decomposition of some mature plant materials, Soil Sci. Am. J., 11, 270-279, 1946.

Bhaumik, H. D., and F. E. Clark, Soil moisture tension and microbiological activity, Soil Sci. Am. J., 12, 234-238, 1947.

Binkley, D., Forest Nutrition Management, John Wiley, New York, 1986.

Ceulemans, R., and M. Mousseau, Effects of elevated atmospheric $\mathrm{CO}_{2}$ on woody plants, New Phytol., 127, 425-446, 1994.

Chapin, F. S., III, Effects of multiple environmental stresses on nutrient availability and use, in Response of Plants to Multiple Stresses, edited by H. A. Mooney et al., pp. 67-88, Academic, San Diego, Calif., 1991.

Chapin, F. S., III, P. M. Vitousek, and K. Van Cleve, The nature of nutrient limitation in plant communities, Am. Nat., 127, 48-58, 1986.

Chapin, F. S., III, C. S. H. Walter, and D. T. Clarkson, Growth response of barley and tomato to nitrogen stress and its control by abscisic acid, water relations, and photosynthesis, Planta, 173, 352-366, 1988.

Daubenmire, R., and D. Prusso, Studies of decomposition rates of tree litter,_Ecology, 44, 589-592, 1963.

Davidson, R. L., Micro-organisms, in Grassland Ecosystems of the World: Analysis of Grasslands and Their Uses, edited by R. T. Coupland, pp. 267-276, Cambridge Univ. Press, New York, 1979.

Dodd, J. L., and W. K. Lauenroth, Analysis of the response of a grassland ecosystem to stress, in Perspectives in Grassland Ecology, edited by N. French, pp. 43-58, Springer-Verlag, New York, 1979.

Eamus, D., and P. G. Jarvis, The direct effects of increase in the global atmospheric $\mathrm{CO}_{2}$ concentration on natural and commercial temperate trees and forests, Adv. Ecol. Res., 19, 1-55, 1989.

Ellis, R. C., Response of crop trees of sugar maple, white ash, and black cherry to release and fertilization, Can.J. For. Res., 9, 179$188,1979$.

Evans, J. R., Nitrogen and photosynthesis in the flag leaf of wheat (Triticum aestivum L.), Plant Physiol., 72, 297-302, 1983.

Evans, J. R., Photosynthesis and nitrogen relationships in leaves of $\mathrm{C}_{3}$ plants, Oecologia, 78, 9-19, 1989.

Food and Agriculture Organization/Complex Systems Research Center 
(FAO/CSRC), $0.5^{\circ}$ digitization of FAO-UNESCO [1971] by Complex Systems Research Center, Univ. of N. H., Durham, undated.

Food and Agriculture Organization-United Nations Educational, Scientific Organization (FAO-UNESCO), Soil map of the world, 1:5,000,000, Paris, 1971.

Farquhar, G. D., and S. von Caemmerer, Modelling of photosynthetic response to environmental conditions, in Encyclopedia of Plant Physiology, New Ser., vol 12 B, edited by O. L. Lange et al., pp. 549-587, Springer-Verlag, New York, 1982.

Farquhar, G. D., S. von Caemmerer, and J. A. Berry, A biochemical model of photosynthetic $\mathrm{CO}_{2}$ assimilation in leaves of $\mathrm{C}_{3}$ species, Planta, 149, 79-90, 1980.

Field, C. B., Ecological scaling of carbon gain to stress and resource availability, in Response of Plants to Multiple Stresses, edited by $\mathrm{H}$. A. Mooney and W. E. Winner, pp. 35-65, Academic, San Diego, Calif., 1991.

Gates, D. M., Global biospheric response to increasing atmospheric carbon dioxide concentrations, in Direct Effects of Increasing Atmospheric Carbon Dioxide on Vegetation, edited by B. R. Strain and J. D. Cure, Rep. DOE/ER-0238, pp. 171-184, U. S. Department of Energy, Washington, D. C., 1985.

Gulmon, S. L., and C. C. Chu, The effects of light and nitrogen on photosynthesis, leaf characteristics, and dry matter allocation in the chaparral shrub, Diplacus aurantiacus, Oecologia, 49, 207-212, 1981.

Gunderson, C. A., and S. D. Wullschleger, Photosynthetic acclimation in trees to rising atmospheric $\mathrm{CO}_{2}: \mathrm{A}$ broader perspective, Photosynth. Res., 39, 369-388, 1994.

Harrison, K., W. Broecker, and G. Bonani, A strategy for estimating the impact of $\mathrm{CO}_{2}$ fertilization on soil carbon storage, Global Biogeochem. Cycles, 7, 69-80, 1993.

Houghton, R. A., and D. L. Skole, Carbon, in The Earth as Transformed by Human Action, edited by B. L. Turner, W. C. Clark, R. W. Kates, J. F. Richards, J. T. Mathews, and W. B. Meyer, pp. 393408, Cambridge Univ. Press, New York, 1990.

Houghton, R. A., J. E. Hobbie, J. M. Melillo, B. Moore, B. J. Peterson, G. R. Shaver, and G. M. Woodwell, Changes in the carbon content of terrestrial biota and soils between 1860 and 1980: A net release of $\mathrm{CO}_{2}$ to the atmosphere, Ecol. Monogr., 53, 235-262, 1983.

Houghton, R. A., D. L. Skole, and D. S. Lefkowitz, Changes in the landscape of Latin America between 1850 and 1985, I, Progressive loss of forests, For. Ecol. Manage., 38, 143-172, 1991.

Hunt, H. W., A simulation model for decomposition in grasslands, Ecology, 58, 469-484, 1977.

Idso, K. E., and S. B. Idso, Plant responses to atmospheric $\mathrm{CO}_{2}$ enrichment in the face of environmental constraints: A review of the past 10 years research, Agric. For. Meteorol., 69, 153-203, 1994.

Ino, Y., and M. Monsi, An experimental approach to the calculation of $\mathrm{CO}_{2}$ amount evolved from several soils, Jpn. J. Bot., 20, 153-188, 1969.

Intergovernmental Panel on Climate Change Working Group I (IPCC WGI), Climate Change 1995 - The Science of Climate Change: Contribution of Working Group I to the Second Assessment Report of the Intergovernmental Panel on Climate Change, edited by J. T. Houghton, L. G. Meira Filho, B. A. Callander, N. Harris, A. Kattenberg, and K. Maskell, Cambridge Univ. Press, New York, 1996.

Jenny, H., S. P. Gessell, and T. Bingham, Comparative study on decomposition rates of organic matter in temperate and tropical regions, Soil Sci., 68, 419-432, 1949.

Kicklighter, D. W., J. M. Melillo, W. T. Peterjohn, E. B. Rastetter, A. D. McGuire, and P. A. Steudler, Aspects of spatial and temporal aggregation in estimating regional carbon dioxide fluxes from temperate forest soils, J. Geophys. Res., 99, 1303-1315, 1994.

Kimball, B. A., Carbon dioxide and agricultural yield: An assemblage and analysis of 430 prior observations, Agron. J., 75, 779-788, 1975.

Kimball, B. A., and S. B. Idso, Increasing atmospheric $\mathrm{CO}_{2}$ : Effects on crop yield, water use and climate, Agric. Water Manage., 7, 55-72, 1983.

Lajtha, K., and W. G. Whitford, The effect of water and nitrogen amendments on photosynthesis, leaf demography, and resource-use efficiency in Larrea tridentata, a desert evergreen shrub, Oecologia, 80,341-348, 1989.

Leemans R., and W. P. Cramer, The IIASA database for mean monthly values of temperature, precipitation and cloudiness of a global ter- restrial grid, Res. Rep. RR-91-18, Int. Inst. of Appl. Syst. Anal., (IIASA), Laxenburg, Austria, 1991.

Luo, Y., C. B. Field, and H. A. Mooney, Predicting responses of photosynthesis and root fraction to elevated $\left[\mathrm{CO}_{2}\right]_{\mathrm{a}}$ : Interactions among carbon, nitrogen, and growth, Plant Cell Environ., 17, 1195-1204, 1994.

McGuire, A. D., J. M. Melillo, L. A. Joyce, D. W. Kicklighter, A. L. Grace, B. Moore III, and C. J. Vorosmarty, Interactions between carbon and nitrogen dynamics in estimating net primary productivity for potential vegetation in North America, Global Biogeochem. $\mathrm{Cy}$ cles, 6, 101-124, 1992.

McGuire, A. D., L. A. Joyce, D. W. Kicklighter, J. M. Melillo, G. Esser, and C. J. Vorosmarty, Productivity response of climax temperate forests to elevated temperature and carbon dioxide: A North American comparison between two global models, Clim. Change, 24, 287-310, 1993.

McGuire, A. D., J. M. Melillo, and L. A. Joyce, The role of nitrogen in the response of forest net primary production to elevated atmospheric $\mathrm{CO}_{2}$, Annu. Rev. Ecol. Syst., 26, 473-503, 1995 a.

McGuire, A. D., J. M. Melillo, D. W. Kicklighter, and L. A. Joyce, Equilibrium responses of soil carbon to climate change: Empirical and process-based estimates, J. Biogeogr., 22, 785-796, $1995 \mathrm{~b}$.

McGuire, A. D., D. W. Kicklighter, and J. M. Melillo, Global climate change and carbon cycling in grasslands and conifer forests, in Global Change: Effects on Coniferous Forests and Grasslands (SCOPE 56), edited by A. I. Breymeyer, D. O. Hall, J. M. Melillo, and G. I. Agren, pp. 388-411, John Wiley, New York, 1996.

Melillo, J. M., J. D. Aber, and J. F. Muratore, Nitrogen and lignin control of hardwood leaf litter decomposition dynamics, Ecology, 63, 621-626, 1982.

Melillo, J. M., J. R. Fruci, R. A. Houghton, B. Moore, and D. L. Skole, Land-use change in the Soviet Union between 1850 and 1980: Causes of a net release of $\mathrm{CO}_{2}$ to the atmosphere, Tellus, Ser. B, 40 , 116-128, 1988.

Melillo, J. M., J. D. Aber, A. E. Linkins, A. Ricca, B. Fry, and K. J. Nadelhoffer, Carbon dynamics along the decay continuum: Plant litter to soil organic matter, in Ecology of Arable Land, edited by M. Clarholm and L. Bergstrom, pp. 53-62, Kluwer Acad., Norwell, Mass., 1989a.

Melillo, J. M., P. A. Steudler, J. D. Aber, and R. D. Bowden, Atmospheric deposition and nutrient cycling, in Exchange of Trace Gases Between Terrestrial Ecosystems and the Atmosphere, edited by M. O. Andreae and D. S. Schimel, pp. 263-280, John Wiley, New York, $1989 \mathrm{~b}$.

Melillo, J. M., A. D. McGuire, D. W. Kicklighter, B. Moore III, C. J. Vorosmarty, and A. L. Schloss, Global climate change and terrestrial net primary production, Nature, 363, 234-240, 1993.

Melillo, J. M., D. W. Kicklighter, A. D. McGuire, W. T. Peterjohn, and K. M. Newkirk, Global change and its effects on soil organic carbon stocks, in Role of Nonliving Organic Matter in the Earth's Carbon Cycle, edited by R. G. Zepp and C. Sonntag, pp. 175-189, John Wiley, New York, 1995.

Melillo, J. M., I. C. Prentice, G. D. Farquhar, E. -D. Schulze, and O. E. Sala, Terrestrial biotic responses to environmental change and feedbacks to climate, in Climate Change 1995 - The Science of Climate Change: Contribution of Working Group I to the Second Assessment Report of the Intergovernmental Panel on Climate Change, edited by J. T. Houghton, L. G. Meira Filho, B. A. Callander, N. Harris, A. Kattenberg, and K. Maskell, pp. 447-481, Cambridge Univ. Press, New York, 1996a.

Melillo, J. M., R. A. Houghton, D. W. Kicklighter, and A. D. McGuire, Tropical deforestation and the global carbon budget, Annu. Rev. Energy Environ., 21, 293-310, $1996 \mathrm{~b}$.

Miller, H. G., Forest fertilization: Some guiding concepts, Forestry, 54, 157-167, 1981.

Miller, R. D., and D. D. Johnson, The effect of soil moisture tension on carbon dioxide evolution, nitrification, and nitrogen mineralization, Soil Sci. Soc. Am. J., 28, 644-647, 1964.

Mitchell, H. L., and R. F. Chandler Jr., The nitrogen nutrition and growth of certain deciduous trees of northeastern United States, Black Rock For. Bull., 11, 1-94, 1939.

Mitchell, J. F. B., S. Manabe, V. Meleshko, and T. Tokioka, Equilibrium climate change --And its implications for the future, in Climate Change: The IPCC Scientific Assessment, edited by J. T. Houghton et al., pp. 131-172, Cambridge Univ. Press, New York, 1990. 
Mooney, H. A., B. G. Drake, R. J. Luxmoore, W. C. Oechel, and L. F. Pitelka, Predicting ecosystem responses to elevated $\mathrm{CO}_{2}$ concentrations, BioScience, 2, 96-104, 1991.

Myers, N., Tropical forests: Present status and future outlook, Clim. Change, 19, 3-32, 1991.

National Center for Atmospheric Research (NCAR)/Navy, Global 10minute elevation data, digital tape available through Nat. Oceanic and Atmos. Admin., Nat. Geophys. Data Cent., Boulder, Colo., 1984.

Pan, Y., Sensitivity of terrestrial ecosystems to elevated atmospheric $\mathrm{CO}_{2}$ : Comparison of model simulation studies to $\mathrm{CO}_{2}$ effects. Bull. Ecol. Soc. Am., 76, 205, 1995.

Pan, Y., A. D. McGuire, D. W. Kicklighter, and J. M. Melillo, The importance of climate and soils for estimates of net primary production: A sensitivity analysis with the Terrestrial Ecosystem Model, Global Change Biol., 2, 5-23, 1996.

Pastor, J., J. D. Aber, C. A. McClaugherty, and J. M. Melillo, Aboveground production and $\mathrm{N}$ and $\mathrm{P}$ cycling along a nitrogen mineralization gradient on Blackhawk Island, Wisconsin, Ecology, 65, 256268, 1984.

Peterson, C., Regional growth and response analysis for unthinned Douglas-fir, in Regional Forest Nutrition Research Project Biennial Report, 1980-82, pp. 3-25, Univ. of Wash. Coll. of For. Resour., Seattle, 1982.

Pettersson, R., and A. J. S. McDonald, Effects of nitrogen supply on the acclimation of photosynthesis to elevated $\mathrm{CO}_{2}$, Photosynth. Res., 39, $389-400,1994$.

Poorter, H., Interspecific variation in the growth response of plants to an elevated ambient $\mathrm{CO}_{2}$ concentration, Vegetatio, 104/105, 77-97, 1993.

Raich, J. W., E. B. Rastetter, J. M. Melillo, D. W. Kicklighter, P. A. Steudler, B. J. Peterson, A. L. Grace, B. Moore III, and C. J. Vorosmarty, Potential net primary productivity in South America: Application of a global model, Ecol. Appl., 1, 399-429, 1991.

Risser, P. G., E. C. Birney, H. D. Blocker, S. W. May, W. J. Parton, and J. A. Wiens, The True Prairie Ecosystem, Van Nostrand Reinhold, New York, 1981.

Safford, L. O., and S. M. Filip, Biomass and nutrient content of 4-yearold fertilized and unfertilized hardwood stands, Can. J. For. Res., 4, 549-554, 1974.

Sage, R. F., Acclimation of photosynthesis to increasing atmospheric $\mathrm{CO}_{2}$ : The gas exchange perspective, Photosynth. Res., 39, 351-368, 1994.

Sage, R. F., and R. W. Pearcy, The nitrogen use efficiency of $C_{3}$ and $C_{4}$ plants, I, Leaf nitrogen, growth, and biomass partitioning in Chenopodium albion (L.) and Amaranthus retroflexus (L.), Plant Physiol., 84, 954-958, 1987a.

Sage, R. F., and R. W. Pearcy, The nitrogen use efficiency of $C_{3}$ and $C_{4}$ plants, II, Leaf nitrogen effects on the gas exchange characteristics of Chenopodium albion (L.) and Amaranthus retroflexus (L.), Plant Physiol., 84, 959-963, 1987b.

Sarmiento, J. L., C. Le Quere, and S. W. Pacala, Limiting future atmospheric carbon dioxide, Global Biogeochem. Cycles, 9, 121-137, 1995.

Schimel, D. S., B. H. Braswell, E. A. Holland, R. McKeown, D. S. Ojima, T. H. Painter, W. J. Parton, and A. R. Townsend, Climatic, edaphic, and biotic controls over storage and turnover of carbon in soils, Global Biogeochem. Cycles, 8, 279-293, 1994.

Schlesinger, W. H., Biogeochemistry: An Analysis of Global Change, Academic, San Diego, Calif., 1991.

Shaver, G. R., and F. S. Chapin, III, Response of fertilization by various plant growth forms in an Alaskan tundra: Nutrient accumulation and growth, Ecology, 61, 662-675, 1980.

Shaver, G. R., and F. S. Chapin III, Effect of fertilization on production and biomass of tussock tundra, Alaska, U.S.A., Arct. Alp. Res., 18, 261-268, 1986.

Shaver, G. R., and F. S. Chapin III, Production: Biomass relationships and element cycling in contrasting arctic vegetation types, Ecol. Monogr., 61, 1-31, 1991.

Sollins, P., C. C. Grier, F. M. McCorison, K. Cromack, Jr., R. Fogel, and R. L. Fredriksen, The internal element cycles of an old-growth Douglas-fir ecosystem in western Oregon, Ecol. Monogr., 50, 261$285,1980$.

Sommers, L. E., C. M. Gilmour, R. E. Wildung, and S. M. Beck, The effect of water potential on decomposition processes in soils, in Water Potential Relations in Soil Microbiology, edited by J. F. Parr, W. R. Gardner and L. F. Elliott, Spec. Pub. 9, Soil Sci. Soc. Am., 9, 97-117, 1981.

Stott, D. E., L. F. Elliott, R. I. Papendick, and G. S. Campbell, Low temperature or low water potential effects on the microbial decomposition of wheat residue, Soil Biol. Biochem., 18, 577-582, 1986.

Trumbore, S. E., O. A. Chadwick, and R. Amundson, Rapid exchange between soil carbon and atmospheric carbon dioxide driven by temperature change, Science, 272, 393-396, 1996.

Van Cleve, K., and J. Zasada, Response of 70-year-old white spruce to thinning and fertilization in interior Alaska, Can. J. For. Res., 6, 145-152, 1976.

Van Veen, J. A., and E. A. Paul, Organic carbon dynamics in grassland soils, 1, Background information and computer simulation, Can. J. Soil Sci., 61, 185-201, 1981.

VEMAP Members, Vegetation/ecosystem modeling and analysis project: Comparing biogeography and biogeochemistry models in a continental-scale study of terrestrial ecosystem responses to climate change and $\mathrm{CO}_{2}$ doubling, Global Biogeochem. Cycles, 9, 407-437, 1995.

Vitousek, P. M., and R. W. Howarth, Nitrogen limitation on land and in the sea: How can it occur?, Biogeochemistry, 13, 87-115, 1991.

Vitousek, P. M., P. R. Ehrlich, A. H. Ehrlich, and P. A. Matson, Human appropriation of the products of photosynthesis, BioScience, 36, 368-373, 1986.

Vitousek, P. M., L. R. Walker, L. D. Whiteaker, and P. A. Matson, Nutrient limitation to plant growth during primary succession, Biogeochemistry, 23, 197-215, 1993.

Vorosmarty, C.J., B. Moore III, A. L. Grace, M. P. Gildea, J. M. Melillo, B. J. Peterson, E. B. Rastetter, and P. A. Steudler, Continental scale models of water balance and fluvial transport: An application to South America, Global Biogeochem. Cycles, 3, 241-265, 1989.

Watson, R. H., H. Rodhe, H. Oeschger, and U. Siegenthaler, Greenhouse gases and aerosols, in Climate Change: The IPCC Scientific Assessment, edited by J. T. Houghton et al., pp. 5-40, Cambridge Univ. Press, New York, 1990

Watson, R. T., L. G. M. Filho, E. Sanhueza, and A. Janetos, Greenhouse gases: Sources and Sinks, in Climate Change 1992: The Supplementary Report to the IPCC Scientific Assessment, edited by J. T. Houghton et al., pp. 25-46, Cambridge Univ. Press, New York, 1992.

Wong, S. C., Elevated atmospheric partial pressure of $\mathrm{CO}_{2}$ and plant growth, I, Interactions of nitrogen nutrition and photosynthetic capacity in $\mathrm{C}_{3}$ and $\mathrm{C}_{4}$ plants, Oecologia, 44, 68-74, 1979.

Wullschleger, S. D., Biochemical limitations to carbon assimilation in $C_{3}$ plants --A retrospective analysis of the $A / C_{1}$ curves from 109 species, J. Exp. Bot., 44, 907-920, 1993.

Wullschleger, S. D., W. M. Post, and A. W. King, On the potential for a $\mathrm{CO}_{2}$ fertilization effect in forests: Estimates of the biotic growth factor based on 58 controlled-exposure studies, in Biotic Feedbacks in the Global Climatic System, edited by G. M. Woodwell and F. T. Mackenzie, pp. 85-107, Oxford Univ. Press, New York, 1995.

Xiao, X., D. W. Kicklighter, J. M. Melillo, A. D. McGuire, P. H. Stone, and A. P. Sokolov, Responses of primary production and total carbon storage to changes in climate and atmospheric $\mathrm{CO}_{2}$ concentration, Tellus, in press, 1997.

J. Helfrich, D. W. Kicklighter, J. M. Melillo, Y. Pan, and X. Xiao, The Ecosystems Center, Marine Biological Laboratory, Woods Hole, MA 02543. (e-mail: jhelfric@lupine.mbl.edu; dkick@lupine.mbl.edu; jmelillo@lupine.mbl.edu; yudepan@lupine.mbl.edu; xiao@lupine.mbl. edu)

A. D. McGuire, U.S. Geological Survey, Alaska Cooperative Fish and Wildlife Research Unit, University of Alaska Fairbanks, Fairbanks, AK 99775. (e-mail: ffadm@aurora.alaska.edu)

B. Moore III, A. L. Schloss, and C. J. Vorosmarty, Complex Systems Research Center, Institute for the Study of Earth, Oceans, and Space, University of New Hampshire, Durham, NH 03824. (e-mail: b.moore@unh.edu; ag@ecos.unh.edu; cv@cycling.unh.edu)

(Received February 1, 1996; revised December 1, 1996; accepted January 3, 1997.) 